\title{
Transmission of SARS-CoV-2 from pre and asymptomatic infected individuals. A systematic review (Version 1).
}

\author{
Tom Jefferson ${ }^{1}$, Elizabeth A. Spencer ${ }^{2}$, Jon Brassey ${ }^{3}$, Igho J. Onakpoya ${ }^{1}$, Elena C. Rosca ${ }^{4}$, Annette Plüddemann², \\ David H. Evans ${ }^{5}$, John M. Conly ${ }^{6}$, Carl J. Heneghan ${ }^{2}$. \\ 1. Department for Continuing Education, University of Oxford, Rewley House, 1 Wellington Square, Oxford OX1 2JA, UK; \\ 2. Centre for Evidence Based Medicine, Nuffield Department of Primary Care Health Sciences, University of Oxford, Radcliffe Observatory \\ Quarter, Oxford, OX2 6GG, UK \\ 3. Trip Database Ltd, Glasllwch Lane, Newport, NP20 3PS, UK \\ 4. Victor Babes University of Medicine and Pharmacy, Piața Eftimie Murgu 2, Timișoara 300041, Romania \\ 5. Li Ka Shing Institute of Virology and Dept. of Medical Microbiology \& Immunology, University of Alberta \\ 6. Departments of Medicine, Microbiology, Immunology \& Infectious Diseases, and Pathology \& Laboratory Medicine, Synder Institute for \\ Chronic Diseases and O'Brien Institute for Public Health, Cumming School of Medicine, University of Calgary and Alberta Health Services, \\ Calgary, Canada.
}

\section{Corresponding author: Tom Jefferson tom.jefferson@conted.ox.ac.uk}

The protocol for this review is accessible: T Jefferson, A Plüddemann, EA Spencer, J Brassey, EC Rosca, I Onakpoya, C Heneghan, DH Evans, J Conly. The evidence on transmission dynamics of COVID-19 from pre- and asymptomatic cases: protocol for a systematic review (Version 2) medRxiv 2021.05.06.21256615; doi:https://doi.org/10.1101/2021.05.06.21256615

\begin{abstract}
Background

The transmission role of SARS-Cov-2 infected persons who develop symptoms post testing (pre symptomatics) or not at all throughout the course of positivity (asymptomatics) is unknown. We carried out a systematic review of available evidence to determine whether they were infectious or not and if so for how long and their probable contribution to the pandemic spread of SARS-CoV-2.
\end{abstract}

\section{Methods}

We searched LitCovid, medRxiv, Google Scholar and the WHO Covid-19 databases and reference lists of included studies. Search terms were COVID-19, SARS-CoV-2, transmission, asymptomatic, presymptomatic and appropriate synonyms. Searches were carried out to 31 March 2021. We included studies on people exposed to SARS CoV-2 within 2-14 days (incubation time) of close contact or suspected community or institutional exposure to index asymptomatic (at the time of observation) infected individuals, as defined in the study. We included studies with a proven or hypothesised chain of transmission with secondary case infected based on fulfilling a confirmed or probable case definition and confirmation of infectiousness and transmission outcome based either on serial PCR cycle threshold readings or viral culture or gene sequencing or any combination thereof and adequate follow up. We assessed the reliability of eliciting symptom and signs compatible with contemporary knowledge and extracted documentation of the likelihood of transmission, presence of replicating virus and/or documentation of phylodynamics (genetic sequence lineage) and/or adequate follow-up and reporting of symptoms and signs. We wrote to all included studies corresponding authors to request further details and assessed likelihood of transmission using adapted causality criteria.

\section{Results}

We included 18 studies from a variety of settings. Because of the current lack of standardized methodology and clear reporting criteria there was substantial methodological variation in transmission studies. Asymptomatic prevalence at the time of initial testing varied from $12.5 \%$ to $100 \%$ and of these $6 \%$ to $100 \%$ were pre-symptomatic cases, depending on the setting and the methods of case ascertainment and the population. Nursing/care home facilities reported high rates of presymptomatic: $50 \%-100 \%$ ( $n=3$ studies). Fifteen studies were classified as high risk and three studies at moderate risk of symptom ascertainment bias. In practice, this assessment means that high-risk studies may be less likely to distinguish between pre-symptomatic and asymptomatic cases. Six of the asymptomatic studies and four presymptomatic studies reported growing infectious virus although the data was too sparse to determine duration of infectiousness. Three studies were judged as providing possible and three of probable/likely evidence of asymptomatic transmission of SARs-CoV-2. Five studies provided evidence of possible and two of probable/likely presymptomatic transmission of SARs-CoV-2. Author response rate was $100 \%$.

\section{Conclusions}

Reliable studies included here provide probable evidence of transmission of SARS-CoV-2 from presymptomatic and asymptomatic individuals. Single point in time estimates and binary PCR testing alone cannot provide reliable information on symptom status and information on infectivity. The number of studies and asymptomatic and presymptomatic cases eligible for inclusion was low, with more data and international standardisation of methods needed to further reduce uncertainty.

Keywords: SARS-CoV-2; Transmission; Levels of evidence; Asymptomatic cases; Presymptomatic cases. 
medRxiv preprint doi: https://doi.org/10.1101/2021.07.28.21261254; this version posted July 31, 2021. The copyright holder for this preprint (which was not certified by peer review) is the author/funder, who has granted medRxiv a license to display the preprint in perpetuity. It is made available under a CC-BY-NC-ND 4.0 International license.

\section{Introduction}

The overarching aim of the WHO's Global Strategic Preparedness and Response Plan for COVID-19 is to prevent transmission of SARS-CoV-2 and prevent associated illness and death. However, the transmission of the SARS-CoV-2 virus and the disease it causes are not entirely understood, and public health and social measures (PHSMs) for restricting transmission are based on limited data with relatively few high-quality systematic reviews on the transmission of the SARS-CoV-2 virus available. To date, systematic reviews have revealed methodological shortcomings in the included studies that hinder the development of firm conclusions over the transmission dynamics ${ }^{1-5}$.

Several reviews have addressed the prevalence of asymptomatic COVID-19 cases but the design and reporting of studies included in those reviews reveal multiple deficits and biases, which impact the asymptomatic estimates, highlighting the need for more robust evidence ${ }^{5,6}$. Limitations identified include relying on binary PCR testing alone to estimate asymptomatic fractions and onward transmission ${ }^{7,8}$. Previous estimates of the asymptomatic influenza fraction are similarly affected by low quality study designs and methods. In addition, the role of cases that remain without symptoms or signs throughout the active phase (asymptomatic) of illness and those who have not developed symptoms or signs yet when surveyed (pre-symptomatic) is at present unclear, partly because of limitations in the methodologies employed in the studies ${ }^{5}$, 9 .

A lack of standardised methods requires integrating clinical, epidemiologic, molecular and laboratory evidence into a framework that identifies higher-quality evidence to reduce the uncertainty over the transmission dynamics of acute respiratory pathogens, including SARSCoV-2. The framework requires studies that use comprehensive and serial screening for symptoms ${ }^{5,910}$ and the use of high-level confirmatory evidence of infection including viral culture and/or whole-genome sequencing to indicate replicable, infectious virus or confirmation of identical sequences and a robust epidemiologic link ${ }^{10}$. The framework is a work in progress as scientific understanding in this area evolves.

Objectives: To provide a rapid summary and evaluation of relevant data on the transmission of SARS-CoV-2 from pre and asymptomatic individuals, report essential policy implications, and highlight research gaps that require attention.

\section{Methods}

This review is part of a series of living reviews ${ }^{1-4}$ updated as new and vital research is published. The review protocol is available at: medRxiv 2021.05.06.21256615; doi: https://doi.org/10.1101/2021.05.06.21256615. We set out to address the following questions:

1. Are asymptomatic or presymptomatic PCR positive individuals infectious;

2. If asymptomatic PCR positive individuals are infectious, what proportion are infectious and what is the duration of infectiousness;

3. What is the relationship between infectiousness and PCR cycle threshold;

4. Is there evidence of a chain of transmission that establishes asymptomatic and/or presymptomatic transmission of SARs-CoV-2?

\section{Search Strategy}


medRxiv preprint doi: https://doi.org/10.1101/2021.07.28.21261254; this version posted July 31, 2021. The copyright holder for this preprint (which was not certified by peer review) is the author/funder, who has granted medRxiv a license to display the preprint in perpetuity. It is made available under a CC-BY-NC-ND 4.0 International license.

The following electronic databases were searched: LitCovid, medRxiv, Google Scholar and the WHO Covid-19 database. Search terms were COVID-19, SARS-CoV-2, transmission, asymptomatic, presymptomatic and appropriate synonyms. Also, the reference lists of included studies were searched for additional relevant studies. Searches were carried out up to 31 March 2021.

WHO Covid-19 Database (https://search.bvsalud.org/global-literature-on-novel-coronavirus2019-ncov/). The global literature cited in the WHO COVID-19 database is updated daily (Monday through Friday) from searches of bibliographic databases, hand searching, and the addition of other expert-referred scientific articles.

LitCovid (https://www.ncbi.nlm.nih.gov/research/coronavirus/)

A curated literature hub for tracking up-to-date scientific information about the 2019 novel Coronavirus. It is a comprehensive resource on the subject, providing central access to relevant articles in PubMed.

MedRxiv (https://www.medrxiv.org/)

A free online archive and distribution server for complete but unpublished manuscripts (preprints) in the medical, clinical, and related health sciences.

\section{Google Scholar (https://scholar.google.com/)}

Provides a broad search for scholarly literature across many disciplines and sources: articles, theses, books, abstracts from academic publishers, professional societies, online repositories, universities and other websites.

We also searched the bibliographies of retrieved systematic reviews.

\section{Inclusion criteria}

We included prospective or retrospective observational studies, including case series and ecological designs, or interventional studies including randomised trials and clinical reports, outbreak reports, case-control studies and experimental studies. Studies incorporating models to describe observed data were included; however, studies reporting solely predictive modelling will be excluded. Single case reports were excluded, as no case report would have information on secondary cases. Studies not reporting data by symptom status were excluded as those with a single observation point. This is because a single observation or inadequate follow up cannot distinguish between presymptomatic, symptomatic and asymptomatic cases.

Studies were included if they reported the following information:

Population: people exposed to SARS CoV-2 within 2-14 days (incubation time) of close contact or suspected community or institutional exposure to index asymptomatic (at the time of observation) infected individuals, as defined in the study.

Reference: secondary case infected based on fulfilling a confirmed or probable case definition Target: level 3 / level 4 evidence with confirmed transmission outcome ${ }^{10}$.

We modified our original protocol to define the contribution to our evidence base from included studies. First, we included all studies satisfying our overall inclusion criteria. Second, for assessing the chain of transmission (question 4), we included those studies which identified index cases and estimated the potential for secondary transmission and thus allowed for analysis. The data extracted to document transmission included i) documentation of the likelihood of transmission; ii) presence of replicating virus and/or documentation of 
medRxiv preprint doi: https://doi.org/10.1101/2021.07.28.21261254; this version posted July 31, 2021. The copyright holder for this preprint (which was not certified by peer review) is the author/funder, who has granted medRxiv a license to display the preprint in perpetuity. It is made available under a CC-BY-NC-ND 4.0 International license.

phylodynamics (genetic sequence lineage); and/or iii) adequate follow-up and reporting of symptoms and signs. [See box 1 for explanation]. For relevant studies, where necessary, one review author wrote to the corresponding author (with one reminder if necessary) to request further details.

\section{Box 1}

\section{i. Was transmission documented?}

i1. Was the chain of transmission adequately described and reported?

Demonstrable and replicable chain of transmission (Gwaltney's postulates ${ }^{11}$ ).

- Viral growth at the proposed anatomic site of origin;

- Viral contaminant reaches portal of entry of new host;

- The results of the study are replicated independently based on the methods detailed in the first study.

The last item should be considered an ideal aim, as many transmission studies are one-off and observational. Outlying studies and those that reach different conclusions should be assessed to ascertain reasons for diversity.

i2. Are the circumstances of transmission adequately assessed and reported?

- Context (exposure takes place).

- Environment (temperature, relative humidity, air exchanges, ultraviolet light etc.).

- Route if known - report if multiple possible routes are entertained or cannot be ruled out.

- Circumstances of exposure, sample collection and symptoms onset are reported.

\section{ii. Were viable replicating viruses and/or phylodynamics documented?}

ii1. The presence of a viable replicating virus with phylodynamics compatible with hypothesised source ascertained.

- $\mathrm{Cq}, \mathrm{Ct}$, Log concentration or number of copies are assessed and reported.

- Observed structural changes in host cells caused by the viral invasion that leads to visible cell lysis and/or other cytopathic phenomena or equivalent in culture.

- Evidence of virus replication consistent with expected growth kinetics in appropriate cell lines.

- Testing for evidence of contamination by other infectious agents.

ii2 Serial Culture adequately described and reported

- Techniques measuring viral infectivity using appropriate cell lines (e.g. viral plaque assay, TCID50 and immunofluorescence).

- For guidance, see section 11-b of Use of cell culture in virology for developing countries in the South-East Asia Region. New Delhi: World Health Organization, Regional Office for South-East Asia; 2. Licence: CC BY-NC-SA 3.0 IGO.

ii3 Genome sequencing adequately described and reported [based on WHO Genomic sequencing of SARS-CoV-2: items ${ }^{12}$ ]

- Genome sampling strategies and study design are considered and reported, including the risk of cross-contamination [item 6.1]. 
medRxiv preprint doi: https://doi.org/10.1101/2021.07.28.21261254; this version posted July 31, 2021. The copyright holder for this preprint (which was not certified by peer review) is the author/funder, who has granted medRxiv a license to display the preprint in perpetuity. It is made available under a CC-BY-NC-ND 4.0 International license.

- The location of sequencing was appropriate [item 6.3.1].

iii. Was there a precise definition of symptoms and signs used, and was follow-up adequate?

- Could the patient flow or data collection methods introduce bias, and were measures to mitigate the bias introduced?

- Inadequate follow-up may misclassify pre-symptomatic individuals ${ }^{3}$. A follow up period is required to assess the presence or absence of symptoms and signs.

- An assessment of other underlying reasons for symptoms and signs should be applied in all cases

A reassessment of symptoms and signs should be recorded by another interviewer in a proportion of the cases as a data quality check.

\section{Quality Assessment}

There are no formal quality assessment and reporting criteria for transmission studies, a situation reminiscent of the early days of Evidence-Based Medicine. Some authors have adapted observational checklists to assess quality ${ }^{9}$. However pre-existing tools and adaptations do not adequately account for the biases that might influence the understanding of the chain of transmission and the need to obtain microbiological as well as clinical confirmation of transmission. As this aspect is even more critical in the case of asymptomatic transmission, we created the list in Box 1, included only level 3 / level 4 evidence ${ }^{10}$ and further broke down the contribution of each study. Once we had assessed the items in Box 1, we looked at how each study defined, assessed and reported the absence or presence of signs and symptoms of Covid-19 in the respective populations.

We consider the assessment for the precise definition of symptoms and signs (set in the knowledge when each study was carried out) used and whether the follow up was adequate (item iii) as essential to determining the transmission of SARS-CoV-2 from pre and asymptomatic infected individuals. Incorporating the latter two criteria in the methods was considered essential to minimize bias by applying objective defined symptom criteria, a defined period of symptom assessment both before and after the testing period, and the method of ascertainment. To assess the quality of the symptom methods, one reviewer extracted the information on the symptom methods, the criteria to define those classified as symptomatic, asymptomatic and presymptomatic. We also included the author responses to requests for additional information in our assessment of bias. One clinical reviewer categorized the potential for bias as high, moderate, or low, which was independently checked by a second clinical reviewer. Reasons for the bias assessment for each study were also recorded.

\section{Data extraction}

Search yields were screened in duplicate, and included study data were extracted into templates that included study characteristics, methodological aspects of studies and a summary of the main findings. Two reviewers also extracted data on the inclusion criteria for the review and the data for the transmission analysis. We followed PRISMA reporting guidelines as indicated for systematic or scoping reviews where applicable ${ }^{13}$. Data extraction was performed by one reviewer and independently checked by a second reviewer. In cases of disagreement, a third author arbitrated. 
medRxiv preprint doi: https://doi.org/10.1101/2021.07.28.21261254; this version posted July 31, 2021. The copyright holder for this preprint (which was not certified by peer review) is the author/funder, who has granted medRxiv a license to display the preprint in perpetuity.

\section{Data synthesis and reporting}

Outcomes of interest are listed in the inclusion criteria. We summarised data narratively and reported the outcomes as stated in the paper, including quantitative estimates and measures of dispersion where feasible and relevant. We reported subgroups of results by setting where appropriate and where sufficient details were provided in the included papers (e.g., care homes, detention centres, educational settings, hospitals, households, and passengers). We wrote to all study authors for clarification of methods and data. To assign the likelihood of transmission, two reviewers $(\mathrm{CJH}, \mathrm{TJ})$ used the existing WHO Uppsala Monitoring Centre (UMC) framework standardised case causality assessment and adapted it for SARS-CoV-2 transmission (Appendix C). The causality categories included certain, probable/likely, possible, unlikely or unclear. Clarification was sought from study authors, and where there was disagreement, consensus was reached by discussion.

\section{Results}

The literature searches identified 444 records for screening for inclusion in this review (Figure 1): 388 studies were excluded after title and abstract screening. A further 39 were excluded on full-text analysis (see Figure 1 for the reasons for exclusion).
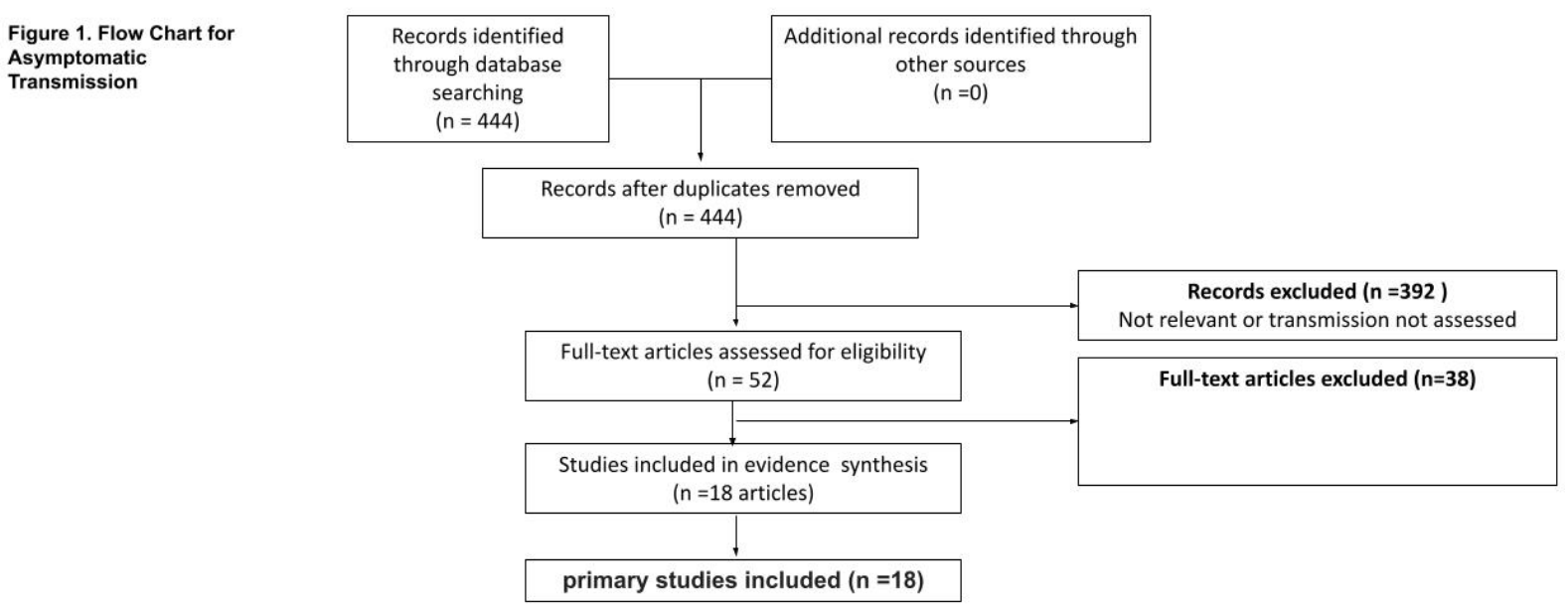

The list of excluded studies is available on request from the corresponding author. Finally, we included 18 studies in the review (See Appendix A for included studies references list). We then wrote to 17 corresponding authors (of 18 papers) and received 17 responses. After receiving the responses, we included 17 studies in the review. See Appendix B for the characteristics of included studies.

Of the 17 included studies, seven were done in the USA (Arons, Gettings, Hershow, Lewis, Pray, Surie, Wallace), 6 in Europe (Borges, de Laval, van Hensenbergen, of which three were in London, UK- Cordery, Jeffery-Smith, Taylor), two in Canada (Ferreira, Soto), one in Japan (cruise ship) (Murata) and one in Australia (flight) (Speake). Most studies were completed in 
medRxiv preprint doi: https://doi.org/10.1101/2021.07.28.21261254; this version posted July 31 , 2021. The copyright holder for this preprint (which was not certified by peer review) is the author/funder, who has granted medRxiv a license to display the preprint in perpetuity. It is made available under a CC-BY-NC-ND 4.0 International license .

2020, with 11 in the first half of the year (Arons, de Laval, Ferreira, Jeffery-Smith, Lewis, Murata, Soto, Speake, Taylor, van Hensenbergen, Wallace) and four in the second half (Borges, Cordery, Pray, Surie). Two studies were done between December and January 2021 (Gettings, Hershow).

Four studies were done in long term care facilities (Arons, Jeffery Smith, Surie, van Hensenbergen), and one among patients in a hospital (Borges). Three studies were based in schools with or without associated households (Cordery, Hershow and Gettings). Other settings included an emergency childcare centre (children and staff) (Soto), a detention centre (Wallace), passengers on a flight (Speake), passengers disembarking from a cruise ship (Murata), staff in an army barracks (Taylor), a military facility (de Laval), healthcare workers in a hospital (Ferreria), households (Lewis) and a university campus (Pray). Included studies had varied designs, including cross-sectional, repeat surveys, symptom-responsive screening designs, and studies addressing varying research questions.

Nasopharyngeal/oropharyngeal/throat samples were collected and tested by RT-PCR in all studies except Hershow, a schools based study that used saliva samples tested by RT-PCR (Hershow). Samples were subjected to viral culture in 9 studies (Arons, Cordery, Lewis, Murata, Pray, Speake, Surie, Taylor, Wallace), and genome sequencing was applied in 10 (Borges, Ferreira, Gettings, Hershow, Jeffery-Smith, Soto, Speake, Taylor, van Hensenbergen, Wallace). In addition, two studies performed serology to assess immunological response (de Laval, Ferreira).

\section{Quality assessment}

Studies with a documented index case (or cases), with confirmation of the index case by serial viral culture, or evidence from $\mathrm{Ct} / \mathrm{Cq} /$ increasing viral load, or evidence from a comprehensive epidemiological investigation on transmission coupled with genomic sequencing, were few (possibly only Cordery, Wallace, Lewis, Soto).

Appendix $C$ shows the quality of symptom assessment for each included study. While each study has strong methodological aspects, the current lack of standardized methodology and clear reporting criteria promotes substantial methodological variation in transmission studies. Examples include differences in measurement thresholds (e.g., temperature above, 37.5, 37.8 or 38C), symptoms collected (the covid list of symptoms has expanded over time), the mode of collection (self-reported, use of a checklist or structured questionnaire, interview or chart review or a combination of methods). Fourteen studies reported the criteria for symptomatic status, four (Arons, Ferreira, Murata, Wallace) reported the criteria for asymptomatic assessment and [Arons, Ferreria, Lewis and Wallace] reported the criteria for presymptomatic status.

Before and after a positive test, the timings of the data collection are crucial for determining symptomatic status. In Surie 2021 (moderate bias), each participant was followed for 42 days from enrollment. For the first 21 days, participants visited every three days; for the next 21 days, participants visited weekly. Symptom assessment and medical chart review were repeated at each visit. At enrollment and visits, participants were interviewed by project staff about symptoms. Symptoms before enrollment were also assessed by healthcare personnel at the facility using a standard symptom list. At the first PCR-positive test, 11 (65\%) participants did not report any COVID-19 symptoms, but all became symptomatic (one on day 25). In Speake, 
medRxiv preprint doi: https://doi.org/10.1101/2021.07.28.21261254; this version posted July 31, 2021. The copyright holder for this preprint (which was not certified by peer review) is the author/funder, who has granted medRxiv a license to display the preprint in perpetuity. It is made available under a CC-BY-NC-ND 4.0 International license.

of 29 passengers who were subsequently identified as PCR-confirmed SARS-CoV-2 linked to the flight, seven had symptoms, but no criteria or follow-up was provided for the 22 passengers presumed asymptomatic. At the time (March 2020), people with no symptoms were not tested because of a lack of availability. This means that those appearing as asymptomatic on the flight could have been pre-symptomatic; incomplete follow-up does not allow a complete picture to emerge.

A checklist or symptom assessment form was used by eight studies (Arons, Hershow, Lewis, Pray, Taylor, Wallace, Cordery, de Laval); interviews by six (Arons Jeffery-Smith, Surie, van Hensbergen, Wallace, de Laval) and one study used text-message based symptom monitoring (Gettings). In Arons et al., a standardized symptom-assessment form was completed by nurses and symptoms present during the preceding 14 days were recorded based on interview and review of medical records. In Wallac,e the investigators administered a structured survey, detainees completed a self-administered, paper-based questionnaire of symptoms in the preceding two months and two weeks, and on the day of each subsequent test, detainees received an abbreviated self-administered, paper-based questionnaire of symptoms experienced since their last test. Responses were verbally verified, and medical history data were abstracted from medical records. Overall, fifteen studies were classified as high risk and three studies at moderate risk of symptom ascertainment bias. In practice, this assessment means that high-risk studies may be less likely to distinguish between pre-symptomatic and asymptomatic status.

\section{Proportion Asymptomatic and Presymptomatic at the time of testing}

Figure 2 shows the fifteen studies that reported asymptomatic cases ( $n=304$ participants). Table 1 shows that the proportion asymptomatic at the time of testing varied significantly across studies (range $12.5 \% \%$ to $100 \%$ ) depending on the setting, case ascertainment methods, and population.

\begin{tabular}{|l|c|c|l|}
\hline Study & $\begin{array}{c}\text { Proportion } \\
\text { asymptomatic at the } \\
\text { time of testing }\end{array}$ & $\begin{array}{c}\text { Presymptomatic (proportion } \\
\text { becoming symptomatic from } \\
\text { asymptomatic) }\end{array}$ & Population/setting \\
\hline Arons & $56.3 \%(27 / 48)$ & $88.9 \%(24 / 27)$ & Skilled nursing home facility \\
\hline Borges & $81.3 \%(39 / 48)$ & $\mathrm{N} / \mathrm{A}$ & Non-COVID-19 hospital ward \\
\hline Cordery & $23.1 \%(3 / 13)$ & $\mathrm{N} / \mathrm{A}$ & $\begin{array}{l}\text { Children and young people in } \\
\text { school settings }\end{array}$ \\
\hline De Laval & $12.5 \%(3 / 24)$ & $\mathrm{N} / \mathrm{A}$ & $\begin{array}{l}\text { Military support facility cases } \\
\text { and contacts }\end{array}$ \\
\hline Ferreria & $\mathrm{N} / \mathrm{A}$ & $\mathrm{N} .4 \%(4 / 9)$ & Healthcare workers \\
\hline Gettings & $\begin{array}{c}21.6 \%(30 / 139): \\
\text { Staff } 9.1 \%(6 / 66)\end{array}$ & $\mathrm{N} / \mathrm{A}$ & Students and staff in school \\
\hline Hershow & $32.1 \%(18 / 56)$ & $50 \%(8 / 16)$ & $\begin{array}{l}\text { Students and staff in elementary } \\
\text { schools }\end{array}$ \\
\hline Jeffery Smith & $100 \%(16 / 16)$ & Care home \\
\hline
\end{tabular}


medRxiv preprint doi: https://doi.org/10.1101/2021.07.28.21261254; this version posted July 31, 2021. The copyright holder for this preprint (which was not certified by peer review) is the author/funder, who has granted medRxiv a license to display the preprint in perpetuity. It is made available under a CC-BY-NC-ND 4.0 International license.

\begin{tabular}{|l|c|c|l|}
\hline Lewis & $16.7 \%(2 / 12)$ & $100 \%(2 / 2)$ & Households \\
\hline Murata & $100 \%(90 / 90)$ & N/A & $\begin{array}{l}\text { Passengers disembarking from } \\
\text { the Diamond Princess cruise } \\
\text { ship }\end{array}$ \\
\hline Pray & $17.9 \%(7 / 39)$ & N/A & University campus \\
\hline Soto & $\begin{array}{l}26.7 \%(8 / 30) \\
\text { Children } 38.9 \%(7 / 18) ;\end{array}$ & N/A & Emergency childcare centre \\
\hline Speake & $75.9 \%(22 / 29)$ & N/A & Passengers on a flight \\
\hline Surie & $64.7 \%(11 / 17)$ & $100 \%(11 / 11)$ & Nursing home residents \\
\hline Talylor & $70.8 \%(17 / 24)$ & N/A & Army barracks \\
\hline $\begin{array}{l}\text { Van } \\
\text { Hensbergen }\end{array}$ & $15.8 \%(3 / 19)^{*}$ & N/A & Long-term care facility \\
\hline Wallace & $44.1 \%(49 / 111)$ & & \\
\hline
\end{tabular}

*asymptomatic (and potentially pre-symptomatic)

Table 1. Numbers of Symptomatic, Asymptomatic and Presymptomatic cases at the time of initial testing.

In Gettings, the proportion asymptomatic was higher in students than staff: $32.9 \%$ vs $9.1 \%$ respectively, $R R=3.6$ ( $95 \%$ Confidence Interval, 1.58 to $8.30, p=0.002)$. In Soto, children were more likely to be asymptomatic: $38.9 \%$ vs $8.3 \%$. Although this result was not significant, RR = $4.67(95 \% \mathrm{Cl}, 0.65$ to $33.30, \mathrm{p}=0.12)$, this observation is consistent with a series from Manitoba, Canada, of 207 children aged up to 17 , where infected children were significantly more likely than adults of being asymptomatic (37.8\% [66/175] vs 7\% [9/130]; $p<0.001$, to have a significantly higher cycle threshold and to be significantly less likely to shed infectious virus ${ }^{14}$.

\section{Presymptomatic}

Table 1 also shows the six studies that reported presymptomatic cases ( $n=50$ participants) [Arons, Ferreria, Jeffery Smith, Lewis, Surie and Wallace]. Three of these were done in nursing/care home facilities and reported high rates of presymptomatic: 50 (8/16) in Jeffrey Smith, 89\% (24/27) in Arons and 100\% (11/11) in Surie Figure 2).

In Jeffrey Smith, the authors report atypical symptoms, which included but were not restricted to new confusion, reduced alertness, fatigue, lethargy, reduced mobility and diarrhoea. Arons reported viable SARS-CoV-2 was isolated from specimens of asymptomatic and presymptomatic residents but provided no level of quantification of the virus. Chronic symptom escalation in the elderly was considered a subjective assessment, and it was noted the elderly might present with more subtle symptoms requiring clinical assessment for detection. In Surie, patients often had difficulty distinguishing acute from chronic symptoms, especially for 
medRxiv preprint doi: https://doi.org/10.1101/2021.07.28.21261254; this version posted July 31, 2021. The copyright holder for this preprint (which was not certified by peer review) is the author/funder, who has granted medRxiv a license to display the preprint in perpetuity. It is made available under a CC-BY-NC-ND 4.0 International license.

nonspecific symptoms such as fatigue and myalgia, which may account for the high percentage of recorded presymptomatic residents.

In Ferreira, the absence of symptoms was confirmed for all participants at the time of testing, and healthcare workers were followed for two weeks. In Lewis, two individuals were identified as testing positive before symptom onset. In Wallace, asymptomatic detainees reported no symptoms throughout observation ( 2 weeks). Presymptomatic cases reported $>1$ symptom after their first positive test with no previous symptoms.

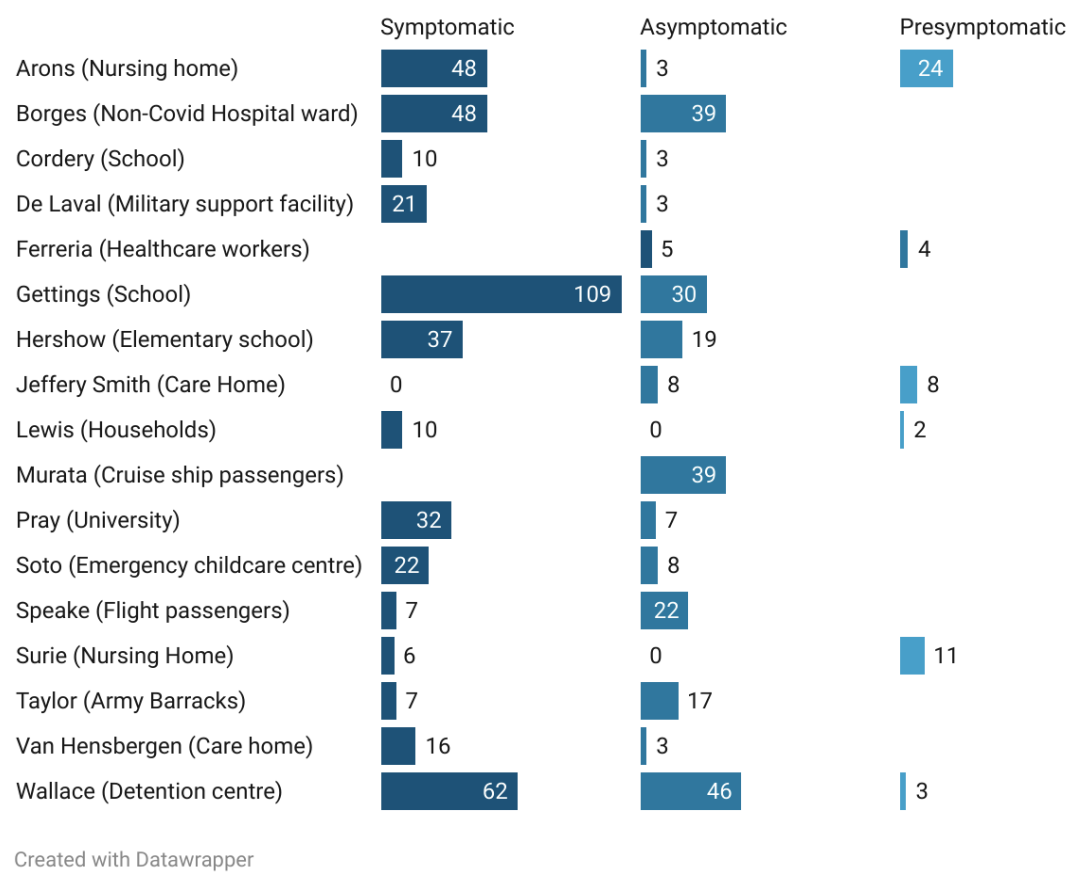

Figure 2. Number of asymptomatic, presymptomatic and symptomatic infected individuals from 17 studies.

\section{Infectious Status of asymptomatic and presymptomatic}

Nine studies [Arons, Cordery, Lewis, Murata, Pray, Speake, Surie, Taylor and Wallace] assessed the infectious status of asymptomatics $(n=7)$ and presymptomatics $(n=4)$. Six asymptomatic studies and four presymptomatic studies demonstrated viral culture. Arons and Wallace assessed both asymptomatic and presymptomatics (see Table 2).

\begin{tabular}{|l|l|l|l|}
\hline Study & $\begin{array}{l}\text { Asymptomatic } \\
\text { infectious }\end{array}$ & $\begin{array}{l}\text { Pre symptomatic } \\
\text { infectious }\end{array}$ & Culture method \\
\hline Arons & $\begin{array}{l}1 / 3 \text { remained } \\
\text { asymptomatic }\end{array}$ & $\begin{array}{l}17 / 24 \text { were } \\
\text { presymptomatic }\end{array}$ & $\begin{array}{l}\text { RT-PCR Positive specimens were inoculated } \\
\text { in Vero-CCL-81 cells. Cells showing the } \\
\text { cytopathic effect were used for SARS-CoV-2 } \\
\text { RT-PCR to confirm isolation and viral growth } \\
\text { in culture. }\end{array}$ \\
\hline
\end{tabular}


medRxiv preprint doi: https://doi.org/10.1101/2021.07.28.21261254; this version posted July 31, 2021. The copyright holder for this preprint (which was not certified by peer review) is the author/funder, who has granted medRxiv a license to display the preprint in perpetuity. It is made available under a CC-BY-NC-ND 4.0 International license.

\begin{tabular}{|c|c|c|c|}
\hline Cordery & $\begin{array}{l}\text { No viral growth } \\
\text { observed }\end{array}$ & & $\begin{array}{l}\text { Samples with high viral load }(\mathrm{Ct} \text { value }<30) \\
\text { were inoculated into Vero cells for the culture } \\
\text { of infectious virus cell culture, as previously } \\
\text { reported. }\end{array}$ \\
\hline Lewis & & $\begin{array}{l}\text { No culturable and } \\
\text { potentially infectious virus } \\
\text { could be isolated }\end{array}$ & Viral cultures were performed at CDC.* \\
\hline Murata & $\begin{array}{l}7 / 39 \text { asymptomatic } \\
\text { carriers }\end{array}$ & & $\begin{array}{l}\text { SARS-CoV-2 carriers who had } \geq \text { two positive } \\
\text { RT-PCR results at the hospital were analyzed } \\
\text { using VeroE6/TMPRSS } 2 \text { cells for the } \\
\text { presence of viable viruses. Cells were } \\
\text { checked every five days to see if they } \\
\text { exhibited CPE. }\end{array}$ \\
\hline Pray & $\begin{array}{l}\text { Six asymptomatics out } \\
\text { of } 32 \text { culture positives. }\end{array}$ & & $\begin{array}{l}\text { Virus culture was attempted on all antigen- } \\
\text { positive or RT-PCR-positive specimens. } \\
\text { Specimens were used to perform a limiting- } \\
\text { dilution inoculation of Vero CCL- } 81 \text { cells, and } \\
\text { RT-PCR tested cultures showing evidence of } \\
\text { CPE for SARS-CoV-2 RNA.*** }\end{array}$ \\
\hline Speake & $\begin{array}{l}1 / 6 \text { asymptomatic } \\
\text { passengers infectious } \\
\text { in the mid-cabin and } \\
3 / 5 \text { in the aft cabin }\end{array}$ & & $\begin{array}{l}\text { Clinical specimens were inoculated in triplicate } \\
\text { wells with Vero-E6 cells at } 80 \% \text { confluency, } \\
\text { incubated at } 37^{\circ} \mathrm{C} \text { in } 5 \% \mathrm{CO} 2 \text {, and inspected } \\
\text { for cytopathic effect daily for up to } 10 \text { days. In- } \\
\text { house PCRs confirmed the identity }\end{array}$ \\
\hline Surie & & 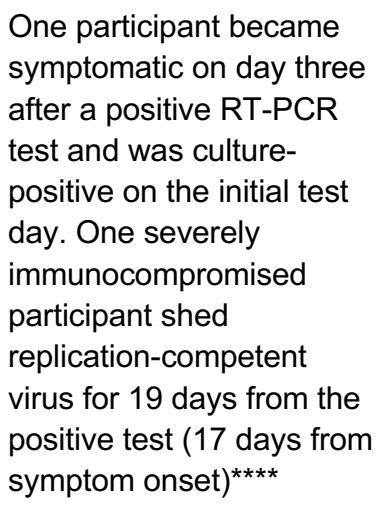 & $\begin{array}{l}\text { All oropharyngeal or anterior nares specimens } \\
\text { with a positive RT-PCR were submitted for } \\
\text { viral culture and inoculated in Vero CCL-81 } \\
\text { cells and observed for CPE daily. When CPE } \\
\text { was observed, the presence of SARS-CoV-2 } \\
\text { was confirmed by RT-PCR. }\end{array}$ \\
\hline Taylor & $\begin{array}{l}\text { Live virus recovered in } \\
6 / 7(86 \%) \text { at test visit } \\
1 .^{* *}\end{array}$ & & $\begin{array}{l}\text { SARS-CoV-2 positive samples with a } \mathrm{Ct}<35 \\
\text { were subjected to virus isolation on Vero E6 } \\
\text { cells swabs, and CPE confirmed virus } \\
\text { detection up to } 14 \text { days after inoculation }\end{array}$ \\
\hline Wallace & $\begin{array}{l}12 / 52 \text { asymptomatic } \\
\text { culture positive }\end{array}$ & $\begin{array}{l}2 \text { of } 3 \text { pre-symptomatics } \\
\text { were culture-positive }\end{array}$ & $\begin{array}{l}\text { All positive samples were shipped to CDC for } \\
\text { viral culture by using Vero-CCL- } 81 \text { cells. The } \\
\text { positive viral culture was confirmed in cells } \\
\text { that showed a cytopathic effect by using rRT- } \\
\text { PCR. }\end{array}$ \\
\hline
\end{tabular}

Table 2. Infectious status of asymptomatic and presymptomatic. Key: CPE=cytopathic effect.

*For further details, see: Severe acute respiratory syndrome coronavirus two from a patient with coronavirus disease, United States. Emerg Infect Dis. 2020;26:1266-73.10.3201/eid2606.200516

** One individual developed symptoms on the day of testing 
medRxiv preprint doi: https://doi.org/10.1101/2021.07.28.21261254; this version posted July 31, 2021. The copyright holder for this preprint (which was not certified by peer review) is the author/funder, who has granted medRxiv a license to display the preprint in perpetuity. It is made available under a CC-BY-NC-ND 4.0 International license.

\footnotetext{
${ }^{* * *}$ Viral recovery was defined as any culture in which the first passage had an N1 Ct at least twofold lower than the corresponding clinical specimen.

${ }^{* * * *}$ data in Figure 4 in the paper identifies the immunocompromised patient as participant $\mathrm{Q}$ and the individual who became symptomatic on day three as participant $\mathrm{K}$.
}

\section{Duration of infectiousness in asymptomatics and presymptomatics}

\section{Asymptomatic}

Murata examined SARS-CoV-2 cell infectivity in samples longitudinally obtained from asymptomatic carriers, and viable viruses from seven were isolated predominantly within seven days after the initial positive PCR test, except for one person who shed viable virus until day 15 (see appendix B). The specimen at day 15 (Ct 30.3) was from a 70-year-old Japanese female with a history of diabetes mellitus and hypertension who had prolonged RT-PCR positivity $>21$ days.

\section{Presymptomatic}

In Arons, 27 residents were classified as asymptomatic (15 reported no symptoms and 12 stable chronic symptoms). In the seven days after their initial positive test, 24 asymptomatic residents $(89 \%)$ had onset of symptoms. The median time to symptom onset was four days (interquartile range, 3 to 5 ).

Lewis did not observe infectiousness in the two presymptomatic individuals. The 33-year-old woman (case 02-01) reported symptoms the day after a positive test, and in a 7-year-old girl, symptoms were reported after two days (case 02-03). In Surie, 9/17 participants (53\%) had replication-competent virus isolated. One severely immunocompromised participant shed replication-competent virus for 19 days from the positive test (17 days from symptom onset) One became symptomatic on day three after a positive RT-PCR, test having been culture positive on the initial test day. The patient was hospitalized on day five and died.

\section{Relationship between infectiousness and PCR cycle threshold in asymptomatics and in presymptomatic}

\section{Asymptomatics}

The median CT of culture-positive individuals in Murata et al. were significantly associated with isolation of viable virus Ct 24.6 (IQR, 20.4-25.2) vs culture-negative Ct 35.9 (IQR, 33.5-37.1), $\mathrm{P}<0.001$. In Wallace, Ct for symptomatic (median 32.7, range 19.7-36.3) were comparable with asymptomatic (32.9, 19.8-36.9). The Median CT of culture-positive was 24.4 (IQR, 21.5-28.0; range, 19.8-33.7), and in the two culture-positive pre-symptomatics, Cts were 20 and 31.1). In Cordery, viral loads were reported as low in $2 / 3$ of the cases (E gene Ct 34.5 and 35.6). In one case, the initial Ct was 26.3 that fell to 22.3 on day 4 (suggesting infectiousness) before increasing to 28.2 by day 8 .

\section{Presymptomatic}

In Lewis, the two presymptomatic household members' initial 'viral shedding' corresponded with medium or high $\mathrm{Ct}$ values (1-2 days before symptom onset). Symptom onset in one patient (case 02-01) was associated with progression from a high $\mathrm{Ct}(>30)$ to a medium value (Ct $20-$ 30 ); symptom onset led to progression to a low value, $<20$ suggesting active viral replication. In the other case (case 02-02, girl aged 7 ), the Ct remained in the range 20-30. Both cases 
medRxiv preprint doi: https://doi.org/10.1101/2021.07.28.21261254; this version posted July 31, 2021. The copyright holder for this preprint (which was not certified by peer review) is the author/funder, who has granted medRxiv a license to display the preprint in perpetuity. It is made available under a CC-BY-NC-ND 4.0 International license.

reported high Cts (>30) on day 14. In Surie, replication-competent viruses could not be cultured above a Ct of 29. In Arons, the Ct values by symptom status were similar (asymptomatic, 25.5; presymptomatic, 23.1; atypical symptoms, 24.2; typical symptoms, 24.8).

\section{What is the evidence of a chain of transmission that establishes asymptomatic and presymptomatic transmission of SARs-CoV-2?}

We used the existing WHO UMC framework and adapted it for SARS-CoV-2 transmission to assign the likelihood of transmission. There is an inevitable element of subjectivity which is why we report the rationale for the categorisation.

\section{Asymptomatics}

Nine studies provided insufficient information [Borges, Ferreira, Francis, Gettings, Murata, Pray, Soto, Speake and Van Hensenbergen] to contribute to assessing the chain of transmission and were therefore classified as unclear. The classification is based on information from the paper and correspondence with authors. Unclear was assigned when a reasonable hypothesis was not formulated or tested or when reliance on consensus genome sequencing was the main component of transmission, but there was no ability or attempt to exclude other sources of infection.

Table 3 includes the six studies (Cordery, De Laval, Hershow, Jeffery Smith, Taylor and Wallace) that classified the probability the study contributes to the chain of asymptomatic transmission of SARs-CoV-2. Three studies were judged as possible (De Laval, Hershow, Jeffery Smith, and three as probable/likely - Cordery, Taylor and Wallace). In Wallace, 46 individuals were reported as asymptomatic, but the methodological limitations mean they could have also been presymptomatic.

\begin{tabular}{|l|l|l|}
\hline Study & Probability & Reason \\
\hline Cordery & Probable/Likely & $\begin{array}{l}\text { Three asymptomatic cases were detected in week 2 of screening. } \\
\text { There is no evidence of wider transmission among children remaining } \\
\text { in school, except the one unexpected cluster of three asymptomatic } \\
\text { cases in one school in the same class. In one of the asymptomatic } \\
\text { cases, the viral load rose on repeat testing to }>4 \text { million copies per } \\
\text { swab, and another asymptomatic household member was identified as } \\
\text { infected (case A Cts: 26.3, 22.3,28.2). However, the case remained } \\
\text { asymptomatic despite viral shedding continuing for at least a week after } \\
\text { an initial positive test. }\end{array}$ \\
\hline De Laval & Possible & $\begin{array}{l}\text { Three cases were asymptomatic. Contact tracing results did not identify } \\
\text { any transmission from asymptomatic to symptomatic cases in this } \\
\text { cluster. }\end{array}$ \\
\hline Hershow & Possible & $\begin{array}{l}\text { Low transmission in schools despite substantial community } \\
\text { transmission. Among the five persons with school-associated cases, } \\
\text { three persons were asymptomatic, and three were exposed to } \\
\text { asymptomatic index patients; four cases were attributed to student-to- } \\
\text { student transmission, and one was to student-to-teacher transmission. }\end{array}$ \\
\hline Jeffery Smith & Possible & $\begin{array}{l}\text { The finding of asymptomatic SARS-CoV-2 infection in care homes that } \\
\text { did not report a single case of COVID-19 and genomic evidence of a }\end{array}$ \\
\hline
\end{tabular}


medRxiv preprint doi: https://doi.org/10.1101/2021.07.28.21261254; this version posted July 31, 2021. The copyright holder for this preprint (which was not certified by peer review) is the author/funder, who has granted medRxiv a license to display the preprint in perpetuity. It is made available under a CC-BY-NC-ND 4.0 International license.

\begin{tabular}{|l|l|l|}
\hline & & $\begin{array}{l}\text { small cluster of staff and residents infected with the same SARS-CoV-2 } \\
\text { lineage in care home F. It was not possible to extract direct } \\
\text { information on transmission from identified asymptomatic index } \\
\text { cases to contacts. }\end{array}$ \\
\hline Taylor & Probable/Likely & $\begin{array}{l}\text { There were 4 cases that all remained asymptomatic throughout with 0 } \\
\text { base difference (genetically indistinguishable); these 4 cases had a link } \\
\text { through one common workplace location. There were another } 4 \\
\text { (different) cases, although two later developed symptoms also with 0 } \\
\text { base difference; other than visiting the same shop and using a common } \\
\text { entrance to the barracks, no common links in the workplace/barracks } \\
\text { setting could be found. }\end{array}$ \\
\hline Wallace & Probable/Likely & $\begin{array}{l}\text { 12/52 asymptomatic had positive viral culture results. A large number of } \\
\text { asymptomatic infections and shedding of replication-competent virus in } \\
\text { asymptomatic participants. The phylogeny indicates within-dormitory } \\
\text { transmission. Individuals are described as asymptomatic, but they } \\
\text { could have also been presymptomatic. }\end{array}$ \\
\hline
\end{tabular}

Table 3. Evidence of the chain of transmission that establishes asymptomatic transmission of SARs-CoV-2.

\section{Presymptomatics}

Table 4 classifies the probability the study contributes to the chain of transmission that establishes presymptomatic transmission of SARs-CoV-2. Of the six studies, Ferreria provided insufficient information to assess the chain of transmission and was judged unclear. Of the five studies, two were assigned as possible [Jeffery Smith, Surie], one unlikely (Lewis) and two as probable/likely (Arons, Wallace). Two studies were classified as unlikely because another explanation (the likely symptomatic index) was more plausible.

\begin{tabular}{|l|l|l|}
\hline Study & Probability & reasons \\
\hline Arons & Probable/Likely & $\begin{array}{l}\text { Viral growth was observed for specimens obtained from 17/24 } \\
\text { presymptomatic residents; 24 presymptomatic residents had a } \\
\text { median rRT-PCR Ct value of 23.1. More than half of residents with } \\
\text { positive test results were asymptomatic at the time of testing and } \\
\text { most likely contributed to the transmission. Staff and residents were } \\
\text { being actively screened for signs and symptoms and either promptly } \\
\text { isolated (residents) or excluded from work (staff) if any were present. }\end{array}$ \\
\hline Jeffery Smith & Possible & $\begin{array}{l}\text { The finding of asymptomatic SARS-CoV-2 infection in care homes } \\
\text { that did not report a single case of COVID-19 and genomic evidence } \\
\text { of a small cluster of staff and residents infected with the same } \\
\text { SARS-CoV-2 lineage occurred in care home F. It was not possible to } \\
\text { extract direct information on transmission from identified pre- } \\
\text { symptomatic index cases to contacts. }\end{array}$ \\
\hline Lewis & Unlikely & $\begin{array}{l}\text { Five households enrolled. Eligibility entailed an identified positive } \\
\text { index case resulting from testing due to symptom onset within each } \\
\text { household; secondary transmission was observed in two } \\
\text { households. WGS for the second household (HH 05-00 } \\
\text { symptomatic) indicated the likely chain of transmission was from 05- } \\
\text { o0 and/or 05-03 (symptomatic) who had genetically identical } \\
\text { infections and were exposed to the same community contact. }\end{array}$ \\
\hline
\end{tabular}


medRxiv preprint doi: https://doi.org/10.1101/2021.07.28.21261254; this version posted July 31, 2021. The copyright holder for this preprint (which was not certified by peer review) is the author/funder, who has granted medRxiv a license to display the preprint in perpetuity. It is made available under a CC-BY-NC-ND 4.0 International license.

\begin{tabular}{|l|l|l|}
\hline & & $\begin{array}{l}\text { WGS indicates that the infections across all four household } \\
\text { members in HH-2 were essentially genetically identical, suggesting } \\
\text { that the index case, 02-00 (symptomatic), was transmitted to all } \\
\text { remaining household members. }\end{array}$ \\
\hline Surie & Possible & $\begin{array}{l}\text { Whole-genome sequencing on eligible specimens (Ct <30) showed } \\
\text { there were only 2-3 single nucleotide variant differences among the } \\
\text { entire set of sequenced genomes, which implied they were likely } \\
\text { from the same source and a single introduction the nursing home. It } \\
\text { is not clear who is the source, and there were six symptomatic } \\
\text { individuals. Thus, 9/17 participants (53\%) had replication-competent } \\
\text { virus isolated. The authors consider that the findings underscore the } \\
\text { potential role of pre-symptomatic carriers in transmission. }\end{array}$ \\
\hline Wallace & Probable/Likely & $\begin{array}{l}\text { 12/52 asymptomatic had positive viral culture results. A large } \\
\text { number of asymptomatic infections and shedding of replication- } \\
\text { competent virus in asymptomatic participants. The phylogeny } \\
\text { indicates within-dormitory transmission. Individuals are described as } \\
\text { asymptomatic, but they could have been presymptomatic. }\end{array}$ \\
\hline
\end{tabular}

Table 4. Evidence of a chain of transmission that establishes presymptomatic transmission of SARs-CoV-2.

\section{Discussion}

Our review was designed to address the question of whether and how much transmission from individuals, either asymptomatic at the time of testing or remained so throughout the length of their positivity, was documented with epidemiological and laboratory evidence of high reliability. This was based on genome sequencing and/or viral culture of samples to indicate infectious potential and epidemiological tracing to identify onward transmission. Sequencing ascertained phylodynamics and lack of contamination or co-infection, while culture indicated whether the isolate could replicate and spread to infect other cells to perpetuate the process. In parallel, PCR positivity identified those who had been in contact with some of the antigens. No single measure sufficed but taken together with clinical history, these four variables can narrow the transmission uncertainty. Despite many studies on transmission, we identified only 18 studies fitting our inclusion criteria. No one study provides the answer but taken together, the included studies stand witness to the efforts of their authors to address the issue of asymptomatic and presymptomatic transmission. A $100 \%$ response rate to reviewers' queries is, to our knowledge, very unusual in systematic reviews ${ }^{15}$. The willingness shown by the corresponding authors of all our included studies in responding to all our queries and providing extra details and data should be capitalised on as the beginning of an international effort to standardise methods and reporting of viral transmission studies drawing together the epidemiological, clinical and virological strands.

Transmission studies are technically challenging to perform, especially amid a pandemic. It is also sometimes difficult to reconstruct events and to separate data for people with no symptoms at the time of the survey and the follow up of their contacts. In some cases, highly cited articles reporting asymptomatic spread turned later to be from an index case who was symptomatic at the time of exposure of contacts but who suppressed symptoms to carry on with her activities ${ }^{16}$, 17. For the Böhmer case, whilst additional information has become available post-publication, clarifying that the suspected index case did indeed suffer symptoms compatible with Covid-19 ${ }^{16}$ 
medRxiv preprint doi: https://doi.org/10.1101/2021.07.28.21261254; this version posted July 31, 2021. The copyright holder for this preprint (which was not certified by peer review) is the author/funder, who has granted medRxiv a license to display the preprint in perpetuity. It is made available under a CC-BY-NC-ND 4.0 International license .

there has not yet been a retraction or correction of that original letter which described, in its title, the index case as asymptomatic. This has allowed the misunderstanding of this case study to perpetuate a false ascertainment of asymptomatic transmission.

The answer to the question of what fraction of the total positives were asymptomatic throughout or only at the point of testing, could not be summarised in a single pooled estimate, given the wide differences in estimates that we have documented $(12.5 \% \%$ to $100 \%$ for asymptomatic at the time of testing and $6 \%$ to $100 \%$ of these being pre-symptomatic cases). Caution should, therefore, be applied to published pooled summary estimates, given the heterogeneity due to the setting, the methods of case ascertainment (including follow-up), the testing and the source population some of whom may have significant cognitive impairment or other factors precluding accurate and reliable symptom ascertainment.

The differences between asymptomatics and pre-symptomatics are also due to the methodologically weak practice of single point-in-time testing (with no or selective follow up) and use of a different sign or symptom definitions. In addition, some studies did not report what list (if any) was used. Several authors also reported difficulty in accurately assessing the symptom profile of elderly patients, suggesting that a more thorough clinical observation, careful observation for signs, and follow up are needed for accurate classification. The likelihood of symptom ascertainment bias is a quality criterion which we inserted after correspondence with the authors of all the studies included in this review and should be incorporated in any future work to identify the role of pre and asymptomatic subjects in the spread of SARS-CoV-2. As such, though, it is a post protocol item due to the evolution of our understanding of the subject matter and is prone to the problems associated with subjective assessments.

Single or point binary PCR testing alone (especially with no Ct reported) cannot give information on infectivity, as the work of Murata et al. shows. A follow up of up to 21 days after the first PCR test of 90 apparently asymptomatic cases from the Diamond Princess with repeated PCR tests, taken in conjunction with the clinical picture and reporting of serial (i.e. on the same subject) Cts, identified 39 true asymptomatic subjects with more than two consecutive or nonconsecutive positive PCR test results at the hospital - seven being potentially infectious.

The serial trend of Ct values, which is linked to the probability of culturing live viruse ${ }^{14,18}$, is thus predictive of likely individual infectiousness, allowing adequate measures to be taken to interrupt the potential spread. We do not have sufficient data to explore the likelihood of infectiousness by age and risk group. Still, the evidence presented in this review shows that a large but variable percentage of asymptomatic subjects goes on to develop symptoms, which a single observation or test will not identify. Therefore, the labelling of a subject as "asymptomatic" based on a single observation is wrong and misleading.

We found evidence of likely infectiousness of both asymptomatics and pre-symptomatics, but we cannot quantify a percentage of infectiousness or contact risk for either category. In part, this is due to the variability of our included populations and perhaps also to varied testing and culture methods that cannot easily translate across different laboratories and cell lines. We exercised caution in comparing results from included studies as there are issues of comparability of cycle threshold values across different $P C R^{19}$. This again points to the requirement for a common approach. 
medRxiv preprint doi: https://doi.org/10.1101/2021.07.28.21261254; this version posted July 31, 2021. The copyright holder for this preprint (which was not certified by peer review) is the author/funder, who has granted medRxiv a license to display the preprint in perpetuity. It is made available under a CC-BY-NC-ND 4.0 International license.

We cannot be certain of the duration of infectiousness but note that there do not seem to be large differences in median cycle thresholds between potentially infectious asymptomatic and pre-symptomatic subjects; again, this is consistent with the observation from the Manitoba series ${ }^{14}$.

Our assessment of the likelihood of transmission is based on what is essentially a headcount, and we phrased it in terms of likelihood, as an absolute proof is not easy to come by, especially in the absence of challenge studies that are difficult to do because of safety and ethics concerns 20, 21. The assessment was primarily based on our correspondence with the authors of the included studies and the additional information provided. There are limitations to this approach; however, our methods are designed to foster dialogue on the ideal methods for transmission and to provide a basis for a joint methods standard for assessing transmission and its reporting

A better understanding of transmission dynamics is essential for pandemic planning as with influenza and other respiratory agents. For example, if a substantial proportion of transmission occurs from individuals who at the time have no symptoms, some control measures such as quarantine and contact tracing might have doubtful value, especially if the duration of infectiousness is brief, but infectivity high, a pattern that fits with the infection of the youngest groups of infected people 22 .

The prolonged period of potential infectiousness reported by Murata et al. ${ }^{23}$ in one of the elderly asymptomatic subjects from the Diamond Princess cruise ship should also be investigated in other settings as it may explain the sudden onset of epidemic foci in nursing homes several days after admission of the last patient to the institution. Again, a single "entry" point test may not be enough. Furthermore, the potential for the elderly to present with more subtle symptoms that may go unrecognized and with a prolonged infectious period is important to understanding and containing outbreaks in care homes.

\section{Policy recommendations}

This review includes a limited body of evidence on which to base public health recommendations. Therefore, research should be embedded into all public health interventions where substantial uncertainty exists, including the question of whether asymptomatic and presymptomatic individuals are important drivers of the transmission of SARS-CoV-2.

\section{Research recommendations}

The observational nature of the studies' design and the lack of universal methods and reporting standard hinder interpretation and point to the absolute need for such standards to be drawn and agreed upon by those interested in researching in vivo transmission of viral respiratory pathogens SARS-CoV-2 in particular. We recommend carrying out longitudinal follow-up studies of at least three weeks' duration during epidemics with consolidated symptoms assessment testing and repeated serial PCRs to elucidate further and clarify the role of those who initially show no symptoms but are positive. At least one study per type of population or setting should be carried out. Graphic presentation of the results could be standardised. We found the reporting of the evolution of transmission in the study by Lewis et al. ${ }^{24}$. particularly helpful and clear. 
medRxiv preprint doi: https://doi.org/10.1101/2021.07.28.21261254; this version posted July 31, 2021. The copyright holder for this preprint (which was not certified by peer review) is the author/funder, who has granted medRxiv a license to display the preprint in perpetuity. It is made available under a CC-BY-NC-ND 4.0 International license.

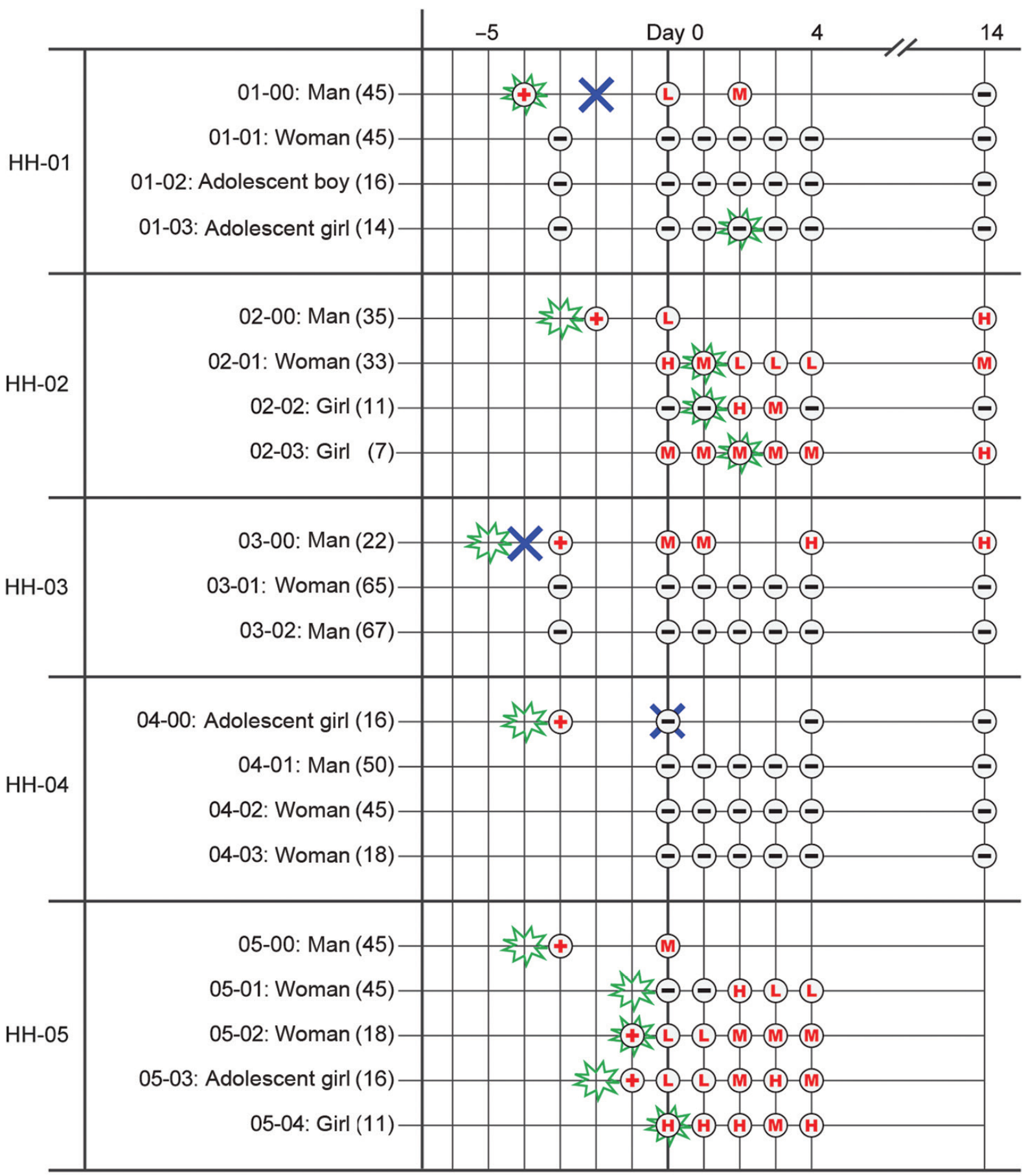

๑ SARS-CoV-2-positive by rRT-PCR, $C_{t}$ unknown

$\odot$ Negative test

(L) SARS-CoV-2-positive by rRT-PCR, $\mathrm{C}_{\mathrm{t}}<20$

Case isolation

(III) SARS-CoV-2-positive by rRT-PCR, $\mathrm{C}_{\mathrm{t}} 20-30$ $\sum_{2}^{M}$ Symptom onset

(H) SARS-CoV-2-positive by rRT-PCR, $\mathrm{C}_{\mathrm{t}}>30$

This is a reproduction of Figure 1 from the study by Lewis et al. ${ }^{25}$. The figure clearly illustrates the results of rRT-PCR for SARS-CoV-2, viral burden and symptom onset among index casepatients and SARS-CoV-2-positive and negative household contacts. Timelines of symptom onset and testing dates before and during the 15- day study period are reported by the 
medRxiv preprint doi: https://doi.org/10.1101/2021.07.28.21261254; this version posted July 31, 2021. The copyright holder for this preprint (which was not certified by peer review) is the author/funder, who has granted medRxiv a license to display the preprint in perpetuity. It is made available under a CC-BY-NC-ND 4.0 International license.

household. Sex and age are reported on the left in brackets. Symptom onset date is only included for household members who tested positive at any time during the study period or for whom onset of symptoms consistent with coronavirus disease prompted an interim visit from investigators. Key: $\mathrm{Ct}=$ cycle threshold; $\mathrm{HH}=$ household; $r \mathrm{RT}-\mathrm{PCR}=$ real-time reverse transcription PCR; SARS-CoV-2 = severe acute respiratory syndrome coronavirus 2.

\section{Conclusion}

In summary, the results of the studies included here with more reliable testing and design, provide probable evidence of transmission of SARS-CoV-2 from presymptomatic and asymptomatic individuals. Single point in time estimates and binary PCR testing alone cannot provide reliable information on symptom status and information on infectivity. The number of studies and asymptomatic and presymptomatic cases eligible for inclusion was low, with more data and international standardisation of methods needed to reduce uncertainty further.

\section{Acknowledgements}

This review would not have been possible without the input of Drs Vitor Borges, Victoria Chu, Victor Ferreira, Frank De Laval, John Jernigan, Jenna R. Gettings, Mitch Van Hensenberg, Nathaniel Lewis, Shamez Ladhani, Matthew Loose, Suzanne McEvoy, lan Pray, Hannah Taylor, Aki Sakurai, Shiranee Shriskandan, Julio Soto, Diya Surie and Megan Wallace. We are grateful for their help.

\section{Conflict of interest statements}

TJ was in receipt of a Cochrane Methods Innovations Fund grant to develop guidance on the use of regulatory data in Cochrane reviews (2015-018). In 2014-2016, he was a member of three advisory boards for Boehringer Ingelheim. TJ was a member of an independent data monitoring committee for a Sanofi Pasteur clinical trial on an influenza vaccine. TJ is occasionally interviewed by market research companies about phase I or II pharmaceutical products for which he receives fees (current). TJ was a member of three advisory boards for Boehringer Ingelheim (2014-16). TJ was a member of an independent data monitoring committee for a Sanofi Pasteur clinical trial on an influenza vaccine (2015-2017). TJ is a relator in a False Claims Act lawsuit on behalf of the United States that involves sales of Tamiflu for pandemic stockpiling. If resolved in the United States favor, he would be entitled to a percentage of the recovery. TJ is coholder of a Laura and John Arnold Foundation grant for development of a RIAT support centre (2017-2020) and Jean Monnet Network Grant, 20172020 for The Jean Monnet Health Law and Policy Network. TJ is an unpaid collaborator to the project Beyond Transparency in Pharmaceutical Research and Regulation led by Dalhousie University and funded by the Canadian Institutes of Health Research (2018-2022). TJ consulted for Illumina LLC on next generation gene sequencing (2019-2020). TJ was the consultant scientific coordinator for the HTA Medical Technology programme of the Agenzia per i Servizi Sanitari Nazionali (AGENAS) of the Italian MoH (2007-2019). TJ is Director Medical Affairs for BC Solutions, a market access company for medical devices in Europe. TJ was funded by NIHR UK and the World Health Organization (WHO) to update Cochrane review A122, Physical Interventions to interrupt the spread of respiratory viruses. TJ is funded by Oxford University to carry out a living review on the transmission epidemiology of COVID-19. Since 2020, TJ receives fees for articles published by The Spectator and other media outlets. TJ is part of a review group carrying out Living rapid literature review on the modes of transmission of SARSCoV-2 (WHO Registration 2020/1077093-0). He is a member of the WHO COVID-19 Infection Prevention and Control Research Working Group for which he receives no funds. TJ is funded 
medRxiv preprint doi: https://doi.org/10.1101/2021.07.28.21261254; this version posted July 31, 2021. The copyright holder for this preprint (which was not certified by peer review) is the author/funder, who has granted medRxiv a license to display the preprint in perpetuity. It is made available under a CC-BY-NC-ND 4.0 International license.

to co-author rapid reviews on the impact of Covid restrictions by the Collateral Global Organisation. TJ's competing interests are also online https://restoringtrials.org/competinginterests-tom-jefferson

CJH holds grant funding from the NIHR, the NIHR School of Primary Care Research, the NIHR BRC Oxford and the World Health Organization for a series of Living rapid review on the modes of transmission of SARs-CoV-2 reference WHO registration No2020/1077093. He has received financial remuneration from an asbestos case and given legal advice on mesh and hormone pregnancy tests cases. He has received expenses and fees for his media work including occasional payments from BBC Radio 4 Inside Health and The Spectator. He receives expenses for teaching EBM and is also paid for his GP work in NHS out of hours (contract Oxford Health NHS Foundation Trust). He has also received income from the publication of a series of toolkit books and for appraising treatment recommendations in non-NHS settings. He is Director of CEBM and is an NIHR Senior Investigator.

DE holds grant funding from the Canadian Institutes for Health Research and Li Ka Shing Institute of Virology relating to the development of Covid-19 vaccines as well as the Canadian Natural Science and Engineering Research Council concerning Covid-19 aerosol transmission. $\mathrm{He}$ is a recipient of World Health Organization and Province of Alberta funding which supports the provision of BSL3-based SARS-CoV-2 culture services to regional investigators. He also holds public and private sector contract funding relating to the development of poxvirus-based Covid-19 vaccines, SARS-CoV-2-inactivation technologies, and serum neutralization testing.

JMC holds grants from the Canadian Institutes for Health Research on acute and primary care preparedness for COVID-19 in Alberta, Canada and was the primary local Investigator for a Staphylococcus aureus vaccine study funded by Pfizer for which all funding was provided only to the University of Calgary. He also received support from the Centers for Disease Control and Prevention (CDC) to attend an Infection Control Think Tank Meeting. He is a member of the WHO Infection Prevention and Control Research and Development Expert Group for COVID-19 and the WHO Health Emergencies Programme (WHE) Ad-hoc COVID-19 IPC Guidance Development Group, both of which provide multidisciplinary advice to the WHO and for which no funding is received.

JB is a major shareholder in the Trip Database search engine (www.tripdatabase.com) as well as being an employee. In relation to this work Trip has worked with a large number of organisations over the years, none have any links with this work. The main current projects are with AXA and Collateral Global. He worked on Living rapid literature review on the modes of transmission of SARS-CoV-2 (WHO Registration 2020/1077093-0) and is part of the review group carrying out a scoping review of systematic reviews and meta-analyses of interventions designed to improve vaccination uptake (WHO Registration 2021/1138353-0).

ECR was a member of the European Federation of Neurological Societies(EFNS) / European Academy of Neurology (EAN) Scientist Panel - Subcommittee of Infectious Diseases (20132017). Since 2021, she is a member of the International Parkinson and Movement Disorder Society (MDS) Multiple System Atrophy Study Group, the Mild Cognitive Impairment in Parkinson Disease Study Group, and the Infection Related Movement Disorders Study Group. She was an External Expert and sometimes Rapporteur for COST proposals (2013, 2016, 2017, 
medRxiv preprint doi: https://doi.org/10.1101/2021.07.28.21261254; this version posted July 31, 2021. The copyright holder for this preprint (which was not certified by peer review) is the author/funder, who has granted medRxiv a license to display the preprint in perpetuity. It is made available under a CC-BY-NC-ND 4.0 International license.

$2018,2019)$ for Neurology projects. She is a Scientific Officer for the Romanian National Council for Scientific Research.

IJO, EAS, and AP have no interests to disclose.

\section{Funding}

$\mathrm{CH}$ has been $\mathrm{PI}$ on $\mathrm{WHO}$ funded transmission work and received funding from the University of Calgary and funding support from the NIHR SPCR. 
medRxiv preprint doi: https://doi.org/10.1101/2021.07.28.21261254; this version posted July 31, 2021. The copyright holder for this preprint (which was not certified by peer review) is the author/funder, who has granted medRxiv a license to display the preprint in perpetuity. It is made available under a CC-BY-NC-ND 4.0 International license.

Appendix A - References of included studies $(n=18)$

Arons 2020: COVID-19 Investigation Team. Presymptomatic SARS-CoV-2 Infections and Transmission in a Skilled Nursing Facility. N Engl J Med. 2020 May 28;382(22):2081-2090. doi: 10.1056/NEJMoa2008457.

Borges 2021: Borges V, Isidro J, Macedo F et al. Nosocomial outbreak of SARS-CoV-2 in a "Non-COVID-19" hospital ward: virus genome sequencing as a key tool to understand cryptic transmission. Viruses. 2021 Apr 1;13(4):604. doi: 10.3390/v13040604.

Cordery 2021: Cordery R, Reeves L, Zhou J et al. Transmission of SARS-CoV-2 by children attending school. Interim report on an observational, longitudinal sampling study of infected children, contacts, and the environment. medRxiv doi:

https://doi.org/10.1101/2021.03.08.21252839

de Laval 2021: de Laval F, Grosset-Janin A, Delon F et al. Lessons learned from the investigation of a COVID-19 cluster in Creil, France: effectiveness of targeting symptomatic cases and conducting contact tracing around them. BMC Infect Dis. 2021 May 19;21(1):457. doi: 10.1186/s12879-021-06166-9.

Ferreira 2021: Ferreira VH, Chruscinski $A$, Kulasingam $V$ et al. Prospective observational study and serosurvey of SARS-CoV-2 infection in asymptomatic healthcare workers at a Canadian tertiary care center. PLoS One. 2021 Feb 16;16(2):e0247258. doi:

10.1371/journal.pone.0247258.

Francis 2021: Francis RV, Billam H, Clarke $M$ et al. The impact of real-time whole genome sequencing in controlling healthcare-associated SARS-CoV-2 outbreaks. medRxiv 2021.04.15.21253894; doi: https://doi.org/10.1101/2021.04.15.21253894

Gettings 2021: Gettings JR, Gold JAW, Kimball A et al. SARS-CoV-2 transmission in a Georgia school district - United States, December 2020-January 2021. Clin Infect Dis. 2021 Apr 17:ciab332. doi: 10.1093/cid/ciab332.

Hershow 2021: Hershow RB, Wu K, Lewis NM, et al. Low SARS-CoV-2 Transmission in Elementary Schools - Salt Lake County, Utah, December 3, 2020-January 31, 2021. MMWR Morb Mortal Wkly Rep. 2021;70(12):442-448. Published 2021 Mar 26.

doi:10.15585/mmwr.mm7012e3

Jeffery-Smith 2020: Jeffery-Smith A, Dun-Campbell K, Janarthanan R et al. Infection and transmission of SARS-CoV-2 in London care homes reporting no cases or outbreaks of COVID19: Prospective observational cohort study, England 2020. Lancet Reg Health Eur. 2021 Apr;3:100038. doi: 10.1016/j.lanepe.2021.100038.

Lewis 2021: Lewis NM, Duca LM, Marcenac $P$ et al. Characteristics and timing of initial virus shedding in Severe Acute Respiratory Syndrome Coronavirus 2, Utah, USA. Emerg Infect Dis. 2021;27(2):352-359. doi:10.3201/eid2702.203517

Murata 2021: Murata T, Sakurai A, Suzuki M et al. Shedding of viable virus in asymptomatic SARS-CoV-2 carriers. mSphere. 2021 May 19;6(3):e00019-21. doi: 10.1128/mSphere.0001921.

Pray 2021: Pray IW, Ford L, Cole D et al. Performance of an antigen-based test for asymptomatic and symptomatic SARS-CoV-2 testing at two university campuses - Wisconsin, September-October 2020. MMWR Morb Mortal Wkly Rep 2021;69:1642-1647. DOI: http://dx.doi.org/10.15585/mmwr.mm695152a3external icon 
medRxiv preprint doi: https://doi.org/10.1101/2021.07.28.21261254; this version posted July 31, 2021. The copyright holder for this preprint (which was not certified by peer review) is the author/funder, who has granted medRxiv a license to display the preprint in perpetuity. It is made available under a CC-BY-NC-ND 4.0 International license.

Soto 2021: Soto JC, Barakat M, Hutter JA et al. Outbreak investigation of SARS-CoV-2 transmission in an emergency childcare centre. Can J Public Health 2021; 112: 566-575. https://doi.org/10.17269/s41997-021-00544-1

Speake 2020: Speake H, Phillips A, Chong T et al. Flight-associated transmission of Severe Acute Respiratory Syndrome Coronavirus 2 corroborated by whole-genome sequencing. Emerg Infect Dis. 2020;26(12):2872-2880. https://doi.org/10.3201/eid2612.203910

Surie 2021: Surie D, Huang JY, Brown AC et al. Infectious period of Severe Acute Respiratory Syndrome Coronavirus 2 in 17 nursing home residents-Arkansas, June-August 2020. Open Forum Infect Dis. 2021 Jan 30;8(3):ofab048. doi: 10.1093/ofid/ofab048.

Taylor 2021: Taylor H, Wall W, Ross D et al. Cross sectional investigation of a COVID-19 outbreak at a London Army barracks: Neutralising antibodies and virus isolation. Lancet Reg Health Eur. 2021 Mar;2:100015. doi: 10.1016/j.lanepe.2020.100015.

van Hensenbergen 2021: van Hensbergen M, den Heijer CDJ, Wolffs $P$ et al. COVID-19: first long-term care facility outbreak in the Netherlands following cross-border introduction from Germany, March 2020. BMC Infect Dis. 2021 May 4;21(1):418. doi: 10.1186/s12879-02106093-9.

Wallace 2021: Wallace $M$, James AE, Silver $R$ et al. Rapid transmission of Severe Acute Respiratory Syndrome Coronavirus 2 in detention facility, Louisiana, USA, May-June, 2020. Emerg Infect Dis. 2021;27(2):421-429. https://doi.org/10.3201/eid2702.204158 
Appendix B - Characteristics of included studies.

\begin{tabular}{|c|c|c|c|c|c|c|}
\hline $\begin{array}{l}\text { Study } \\
\text { (The calendar } \\
\text { time period of } \\
\text { collection ) }\end{array}$ & $\begin{array}{l}\text { Study } \\
\text { population }\end{array}$ & $\begin{array}{l}\text { Brief description } \\
\text { of study }\end{array}$ & $\begin{array}{l}\text { Screening/ testing } \\
\text { methods for COVID-19 } \\
\text { infection }\end{array}$ & $\begin{array}{l}\text { Case definition(s) } \\
\text { including cut-off } \\
\text { values for PCR or } \\
\text { other laboratory } \\
\text { tests. }\end{array}$ & $\begin{array}{l}\text { Symptom } \\
\text { ascertainment, } \\
\text { including follow-up } \\
\text { ascertainment methods }\end{array}$ & Notes \\
\hline $\begin{array}{l}\text { Arons } \\
\text { (Feb-March } \\
\text { 2020) }\end{array}$ & $\begin{array}{l}\text { Skilled } \\
\text { nursing home } \\
\text { facility; } \\
\text { residents with } \\
\text { mean age } 78 \\
\text { years, } \\
\text { Washington, } \\
\text { USA. }\end{array}$ & $\begin{array}{l}\text { Repeated point } \\
\text { prevalence survey } \\
\text { in a care home. } 1 \text { st } \\
\text { case was identified } \\
\text { then a survey done } \\
10 \text { days later, } \\
\text { followed by a } \\
\text { second survey } 7 \\
\text { days subsequently. }\end{array}$ & $\begin{array}{l}\text { NP and OP swabs taken } \\
\text { and subjected to testing } \\
\text { for SARS-CoV-2, using } \\
\text { rRT-PCR, viral culture, } \\
\text { and gene sequencing. }\end{array}$ & $\begin{array}{l}\text { Positive testing } \\
\text { residents were } \\
\text { categorized } \\
\text { as symptomatic } \\
\text { with typical } \\
\text { symptoms (fever, } \\
\text { cough, or } \\
\text { shortness of } \\
\text { breath), } \\
\text { symptomatic with } \\
\text { only atypical } \\
\text { symptoms, } \\
\text { presymptomatic, } \\
\text { or asymptomatic. }\end{array}$ & $\begin{array}{l}\text { Standardized } \\
\text { symptom-assessment } \\
\text { form completed by nurses } \\
\text { for each resident tested, } \\
\text { on the survey day. } \\
\text { Interview and medical } \\
\text { records were used to } \\
\text { ascertain symptoms for } \\
\text { the previous } 14 \text { days. } \\
\text { Asymptomatic positive- } \\
\text { testing residents were } \\
\text { reassessed for symptoms } \\
7 \text { days later. }\end{array}$ & $\begin{array}{l}\text { Direct evidence about } \\
\text { transmission not } \\
\text { presented, indirect } \\
\text { evidence reported about } \\
\text { spread within the care } \\
\text { home. Cognitive } \\
\text { impairment was present } \\
\text { in } 28 / 48 \text { ( } 58 \% \text { ) patients } \\
\text { that were positive for } \\
\text { SARS-CoV-2, reducing } \\
\text { the reliability of their self- } \\
\text { reporting. }\end{array}$ \\
\hline $\begin{array}{l}\text { Borges } \\
\text { (summer } \\
2020)\end{array}$ & $\begin{array}{l}\text { Non-COVID- } \\
19 \text { hospital } \\
\text { ward patients } \\
\text { and staff, } \\
\text { Lisbon and } \\
\text { Tagus valley, } \\
\text { Portugal. }\end{array}$ & $\begin{array}{l}\text { Investigation of a } \\
\text { nosocomial } \\
\text { outbreak, with in- } \\
\text { depth contact } \\
\text { tracing and testing. } \\
\text { After cases were } \\
\text { identified within the } \\
\text { hospital, } 348 \mathrm{HCWs} \\
\text { and } 92 \text { patients } \\
\text { were screened. } \\
\text { Laboratory tests } \\
\text { were performed in } \\
245 \text { individuals }\end{array}$ & $\begin{array}{l}\text { NP and OP swabs were } \\
\text { collected from patients } \\
\text { and HCWs. Positive } \\
\text { SARS-CoV-2 RNA } \\
\text { samples were subjected } \\
\text { to virus genome } \\
\text { sequencing. }\end{array}$ & Not reported. & $\begin{array}{l}\text { Symptoms of fever, cough } \\
\text { or shortness of breath, } \\
\text { were recorded at the time } \\
\text { of testing. }\end{array}$ & $\begin{array}{l}\text { The transmission was } \\
\text { not tracked according to } \\
\text { symptomatology. Study } \\
\text { participants were not } \\
\text { subjected to serial PCR } \\
\text { testing and culture was } \\
\text { not attempted. } \\
\text { Asymptomatic is not } \\
\text { clearly defined, and only } \\
\text { referred to as at the time } \\
\text { of testing, so may not be } \\
\text { persistently } \\
\text { asymptomatic. }\end{array}$ \\
\hline
\end{tabular}




\begin{tabular}{|c|c|c|c|c|c|c|}
\hline $\begin{array}{l}\text { Cordery } \\
\text { (Oct-Dec } \\
2020)\end{array}$ & $\begin{array}{l}\text { School staff, } \\
\text { pupils and } \\
\text { their } \\
\text { households, } \\
\text { London, UK }\end{array}$ & $\begin{array}{l}\text { Sequential } \\
\text { longitudinal } \\
\text { sampling of infected } \\
\text { children, their } \\
\text { contacts, and } \\
\text { surfaces at school } \\
\text { and home. Nose } \\
\text { and throat swabs } \\
\text { were taken, fecal } \\
\text { samples were } \\
\text { collected where } \\
\text { possible. Samples } \\
\text { with Ct value <30 } \\
\text { were inoculated into } \\
\text { Vero cells for } \\
\text { culture. }\end{array}$ & $\begin{array}{l}\text { Case follow-up: } \\
\text { Separate nose, throat, } \\
\text { and hand swabs, saliva } \\
\text { samples, and gingival } \\
\text { crevicular fluid swabs } \\
\text { were obtained from each } \\
\text { case up to } 5 \text { times within } \\
14 \text { days, then weekly } \\
\text { over a second period of } \\
\text { up to } 14 \text { days; also fecal } \\
\text { samples collected where } \\
\text { available. Close contact } \\
\text { follow-up: Combined } \\
\text { nose-throat swabs and } \\
\text { gingival crevicular fluid } \\
\text { swabs were obtained } \\
\text { from each participating } \\
\text { contact on the same day } \\
\text { or as soon as possible } \\
\text { (<48hours) after case } \\
\text { sampling, then weekly } \\
\text { for up to } 28 \text { days. } \\
\text { Samples with high viral } \\
\text { load (Ct value }<30 \text { ) were } \\
\text { inoculated into Vero } \\
\text { cells for culture. }\end{array}$ & $\begin{array}{l}\text { Combined nose- } \\
\text { throat swab testing } \\
\text { positive by RT- } \\
\text { PCR. }\end{array}$ & $\begin{array}{l}\text { Symptom description and } \\
\text { contact history of cases } \\
\text { were collected by } \\
\text { questionnaire, completed } \\
\text { by parent or guardian. }\end{array}$ & $\begin{array}{l}\text { Environmental sampling } \\
\text { was also done in homes } \\
\text { and schools. }\end{array}$ \\
\hline $\begin{array}{l}\text { De Laval } \\
\text { (Feb-March } \\
\text { 2020) }\end{array}$ & $\begin{array}{l}\text { Military } \\
\text { support } \\
\text { facility staff, } \\
\text { France }\end{array}$ & $\begin{array}{l}\text { Outbreak } \\
\text { investigation using a } \\
\text { testing strategy } \\
\text { according to pre- } \\
\text { test probability, after } \\
\text { identification of a } \\
\text { severely ill index } \\
\text { case. Case finding } \\
\text { and contact tracing } \\
\text { with testing of at- } \\
\text { risk contact persons }\end{array}$ & $\begin{array}{l}\text { NP and OP swabs were } \\
\text { taken. Samples positive } \\
\text { by PCR were gene } \\
\text { sequenced. One month } \\
\text { subsequently, serology } \\
\text { was done on all staff, } \\
\text { which was potentially } \\
\text { able to indicate past } \\
\text { infections that ppts did } \\
\text { not report symptoms for } \\
\text { (i.e. asymptomatic). }\end{array}$ & $\begin{array}{l}\text { Confirmed cases } \\
\text { were participants } \\
\text { with positive RT- } \\
\text { PCR test results } \\
\text { and/or positive } \\
\text { serology }\end{array}$ & $\begin{array}{l}\text { The interviewer- } \\
\text { administered a } \\
\text { standardized } \\
\text { questionnaire using an in- } \\
\text { depth interview to } \\
\text { ascertain symptoms and } \\
\text { date of onset, also } \\
\text { information about } \\
\text { contacts in the } 14 \text { days } \\
\text { prior to symptom onset. }\end{array}$ & $\begin{array}{l}\text { Only symptomatic } \\
\text { individuals had swabs } \\
\text { collected. Serology done } \\
\text { one month later was able } \\
\text { to identify participants } \\
\text { who remained } \\
\text { asymptomatic. }\end{array}$ \\
\hline
\end{tabular}




\begin{tabular}{|c|c|c|c|c|c|c|}
\hline & & $\begin{array}{l}\text { who had any } \\
\text { relevant symptoms. } \\
\text { Only symptomatics } \\
\text { were tested. }\end{array}$ & & & & \\
\hline $\begin{array}{l}\text { Ferreria } \\
\text { (April-May } \\
2020)\end{array}$ & $\begin{array}{l}\text { Healthcare } \\
\text { workers, a } \\
\text { large hospital, } \\
\text { Toronto, } \\
\text { Canada }\end{array}$ & $\begin{array}{l}\text { Over a six-week } \\
\text { period, HCWs were } \\
\text { prospectively } \\
\text { enrolled and } \\
\text { underwent one to } \\
\text { six serial NP swabs } \\
\text { for SARS-CoV-2 } \\
\text { PCR testing; study } \\
\text { participants were } \\
\text { required to be } \\
\text { asymptomatic and } \\
\text { not have a previous } \\
\text { diagnosis of } \\
\text { COVID-19. }\end{array}$ & $\begin{array}{l}\text { Serial NP swabs were } \\
\text { taken and subjected to } \\
\text { PCR. Serologic testing } \\
\text { for lgG was performed } \\
\text { on a subset of } \\
\text { asymptomatic HCWs } \\
\text { with no prior known } \\
\text { exposure to SARS-CoV- } \\
2 . \\
\text { Genome sequencing } \\
\text { was performed on } \\
\text { positive swab } \\
\text { specimens. }\end{array}$ & $\begin{array}{l}\text { PCR Ct count cut } \\
\text { off not reported. } \\
\text { For serology, ratio } \\
\text { of ppt sample: } \\
\text { calibration } \\
\text { interpreted as: } \\
<0.8 \text { negative; } 0.8 \\
\text { to }<1.0 \text { borderline; } \\
\text { and } 1.1 \text { lgG } \\
\text { positive. }\end{array}$ & $\begin{array}{l}\text { Symptoms compatible } \\
\text { with COVID-19 included } \\
\text { fever, headache, new or } \\
\text { worsening cough, } \\
\text { shortness of breath, sore } \\
\text { throat, rhinorrhea, } \\
\text { diarrhoea, anosmia, } \\
\text { myalgias, and } \\
\text { conjunctivitis. }\end{array}$ & $\begin{array}{l}\text { The main aim of the } \\
\text { study was to assess the } \\
\text { prevalence of } \\
\text { asymptomatic, positive- } \\
\text { testing HCWs. }\end{array}$ \\
\hline $\begin{array}{l}\text { Francis } \\
\text { (until } \\
\text { November } \\
\text { 2020) }\end{array}$ & $\begin{array}{l}\text { Patients } \\
\text { attending } \\
\text { hospital, and } \\
\text { associated } \\
\text { staff contacts, } \\
\text { Nottingham, } \\
\text { UK }\end{array}$ & $\begin{array}{l}\text { Hospital patients } \\
\text { were screened on } \\
\text { admission } \\
\text { irrespective of } \\
\text { symptomatology; } \\
\text { hospital staff were } \\
\text { tested if } \\
\text { symptomatic or a } \\
\text { local outbreak } \\
\text { occurred. }\end{array}$ & $\begin{array}{l}\text { NP swabs were } \\
\text { subjected to RT-PCR; } \\
\text { positive tests from } \\
\text { samples with some } \\
\text { epidemiological } \\
\text { evidence of linkage were } \\
\text { subject to genome } \\
\text { sequencing; also } \\
\text { surveillance of } \\
\text { sequences was done } \\
\text { using samples with PCR } \\
\text { Ct<30. }\end{array}$ & Not reported. & $\begin{array}{l}\text { No methods for symptom } \\
\text { assessment were } \\
\text { reported. }\end{array}$ & $\begin{array}{l}\text { The study was set up to } \\
\text { examine how whole } \\
\text { genome sequencing can } \\
\text { help identify and control } \\
\text { outbreaks. Clusters of } \\
\text { infections are reported, } \\
\text { with evidence on } \\
\text { epidemiology, PCR, and } \\
\text { genome sequencing. } \\
\text { Transmission from } \\
\text { specific individuals not } \\
\text { reported; transmission } \\
\text { from individuals } \\
\text { established to be } \\
\text { asymptomatic therefore } \\
\text { not reported. }\end{array}$ \\
\hline
\end{tabular}




\begin{tabular}{|c|c|c|c|c|c|c|}
\hline $\begin{array}{l}\text { Gettings } \\
\text { (Dec 2020 - } \\
\text { Jan 2021) }\end{array}$ & $\begin{array}{l}\text { Students and } \\
\text { staff in } \\
\text { schools, } \\
\text { Georgia, USA }\end{array}$ & $\begin{array}{l}\text { Index cases and } \\
\text { their close contacts } \\
\text { in schools were } \\
\text { identified by the } \\
\text { school and public } \\
\text { health staff. } \\
\text { Epidemiology and } \\
\text { WGS were used to } \\
\text { identify transmission } \\
\text { patterns. }\end{array}$ & $\begin{array}{l}\text { In-school contacts: } \\
\text { symptoms assessed, } \\
\text { RT-PCR test on anterior } \\
\text { nasal swab offered. } \\
\text { WGS was done on } \\
\text { PCR- positive samples } \\
\text { with a Ct of < } 32 \text { cycles. }\end{array}$ & $\begin{array}{l}\text { Case is defined as } \\
\text { a student or staff } \\
\text { member who } \\
\text { attended school in } \\
\text { person within } \leq 2 \\
\text { days before } \\
\text { testing PCR or } \\
\text { antigen test } \\
\text { positive. }\end{array}$ & $\begin{array}{l}\text { Symptoms at the time of } \\
\text { testing were recorded, } \\
\text { and for } 14 \text { days, daily } \\
\text { through daily text- } \\
\text { message based symptom } \\
\text { monitoring. }\end{array}$ & $\begin{array}{l}\text { The study aimed to } \\
\text { assess the extent and } \\
\text { settings of transmission } \\
\text { in and related to schools. }\end{array}$ \\
\hline $\begin{array}{l}\text { Hershow } \\
\text { (Dec 2020 - } \\
\text { Jan 2021) }\end{array}$ & $\begin{array}{l}\text { Students and } \\
\text { staff in } \\
\text { elementary } \\
\text { schools } \\
\text { reopening } \\
\text { after } \\
\text { pandemic } \\
\text { related } \\
\text { closure, Utah, } \\
\text { USA. }\end{array}$ & $\begin{array}{l}\text { The screening was } \\
\text { offered to close } \\
\text { contacts of } \\
\text { identified index } \\
\text { cases. Samples } \\
\text { were collected } 5 \text { to } \\
10 \text { days post- } \\
\text { exposure. }\end{array}$ & $\begin{array}{l}\text { Saliva samples (or nasal } \\
\text { samples, if saliva is not } \\
\text { available) are subjected } \\
\text { to RT-PCR. WGS was } \\
\text { performed on positive } \\
\text { samples. }\end{array}$ & $\begin{array}{l}\text { Index case defined } \\
\text { as a student or } \\
\text { staff member with } \\
\text { laboratory- } \\
\text { confirmed } \\
\text { SARS-CoV-2 } \\
\text { infection who had } \\
\text { attended in-person } \\
\text { school while } \\
\text { infectious for at } \\
\text { least } 1 \text { day. }\end{array}$ & $\begin{array}{l}\text { Symptoms and exposures } \\
\text { information were } \\
\text { collected by } \\
\text { questionnaire. }\end{array}$ & $\begin{array}{l}\text { Community transmission } \\
\text { was relatively high at the } \\
\text { time. In-school mask use } \\
\text { and } 3 \mathrm{ft} / 2 \mathrm{~m} \text { distancing } \\
\text { were in place. Reports } \\
\text { low transmission in } \\
\text { schools despite } \\
\text { substantial community } \\
\text { transmission. }\end{array}$ \\
\hline $\begin{array}{l}\text { Jeffery } \\
\text { Smith } \\
\text { (April 2020) }\end{array}$ & $\begin{array}{l}\text { Care homes, } \\
\text { London, UK }\end{array}$ & $\begin{array}{l}\text { Study designed to } \\
\text { look at } \\
\text { asymptomatic } \\
\text { transmission, using } \\
\text { serology and } \\
\text { comparing findings } \\
\text { from } 7 \text { care homes } \\
\text { without outbreaks } \\
\text { (single case or no } \\
\text { cases) to } 6 \text { care }\end{array}$ & $\begin{array}{l}7 \text { non-outbreak } \\
\text { homes investigated with } \\
\text { nasal swabbing for } \\
\text { SARS-CoV-2 RT-PCR } \\
\text { and serology for SARS- } \\
\text { CoV-2 } \\
\text { antibodies five weeks } \\
\text { later. WGS was } \\
\text { performed on RT-PCR } \\
\text { positive samples. }\end{array}$ & $\begin{array}{l}\text { Case definition not } \\
\text { reported. }\end{array}$ & $\begin{array}{l}\text { Staff self-reported } \\
\text { symptom } \\
\text { status during preceding } \\
14 \text { days and at the time of } \\
\text { swabbing; residents' } \\
\text { symptoms were recorded } \\
\text { by staff. Daily monitoring } \\
\text { of each care home by } \\
\text { study staff to identify any } \\
\text { newly symptomatic }\end{array}$ & $\begin{array}{l}\text { This study aimed to } \\
\text { investigate asymptomatic } \\
\text { transmission; it is phase } \\
3 \text { of a series of } \\
\text { investigations in care } \\
\text { homes. }\end{array}$ \\
\hline
\end{tabular}




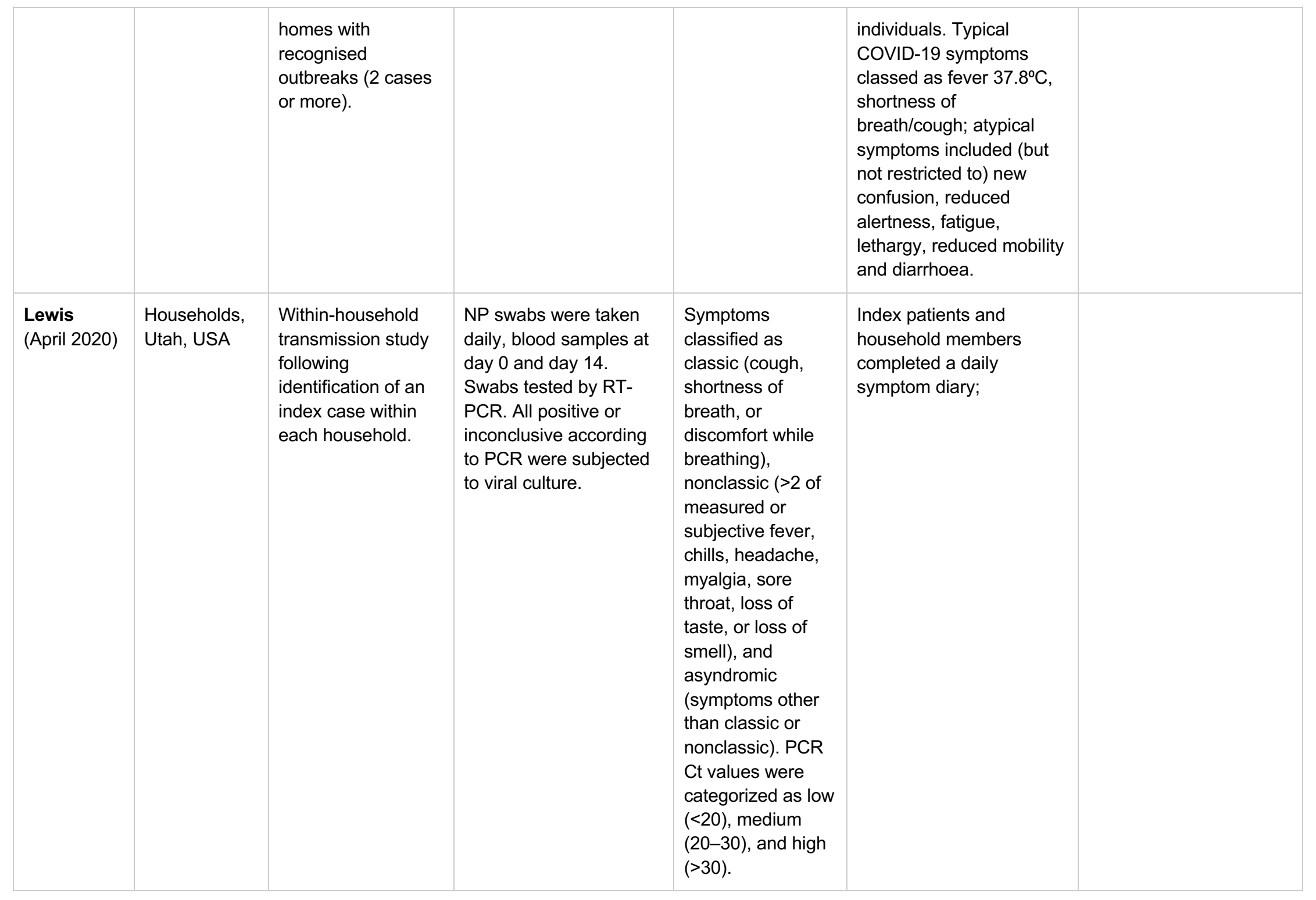




\begin{tabular}{|c|c|c|c|c|c|c|}
\hline $\begin{array}{l}\text { Murata } \\
\text { (Feb 2020) }\end{array}$ & $\begin{array}{l}\text { Passengers } \\
\text { disembarking } \\
\text { from the } \\
\text { Diamond } \\
\text { Princess } \\
\text { cruise ship, } \\
\text { Japan }\end{array}$ & $\begin{array}{l}\text { Observational study } \\
\text { of a cohort of } \\
\text { asymptomatic } \\
\text { passengers and } \\
\text { crew members who } \\
\text { tested positive for } \\
\text { SARS-CoV-2 and } \\
\text { their cabin-mates } \\
\text { who tested negative } \\
\text { and were } \\
\text { transferred from } \\
\text { the cruise ship to } \\
\text { on-shore hospitals } \\
\text { in Japan for } \\
\text { isolation. }\end{array}$ & $\begin{array}{l}\text { Screening RT-PCR of } \\
\text { nasopharyngeal } \\
\text { or throat swabs. } \\
\text { Samples with two or } \\
\text { more positive PCR test } \\
\text { results were subjected } \\
\text { to viral culture. }\end{array}$ & $\begin{array}{l}\text { Ct value of } 40 \text { is } \\
\text { used as a cutoff } \\
\text { for positivity. }\end{array}$ & $\begin{array}{l}\text { Asymptomatic status was } \\
\text { determined at the } \\
\text { time of testing based on } \\
\text { the absence of fever } \\
\text { (temperature of } \\
>=37.5^{\circ} \mathrm{C} \text { ) and clinical } \\
\text { symptoms (cough, } \\
\text { dyspnea, chest pain, sore } \\
\text { throat, and nasal } \\
\text { discharge) by physicians } \\
\text { and nurses }\end{array}$ & $\begin{array}{l}\text { This study was designed } \\
\text { to examine the shedding } \\
\text { of viable viruses from } \\
\text { asymptomatic carriers. }\end{array}$ \\
\hline $\begin{array}{l}\text { Pray } \\
\text { (Sept-Oct } \\
2020)\end{array}$ & $\begin{array}{l}\text { University } \\
\text { campuses, } \\
\text { Wisconsin, } \\
\text { USA }\end{array}$ & $\begin{array}{l}\text { Evaluated } \\
\text { performance of an } \\
\text { antigen } \\
\text { (immunoassay) test } \\
\text { compared with RT- } \\
\text { PCR for SARS- } \\
\text { CoV-2 detection } \\
\text { among } \\
\text { asymptomatic and } \\
\text { symptomatic } \\
\text { persons. }\end{array}$ & $\begin{array}{l}\text { Nasal swabs were } \\
\text { collected from all } \\
\text { consenting participants } \\
\text { and tested using rapid } \\
\text { antigen and RT-PCR. All } \\
\text { specimens testing } \\
\text { positive were subjected } \\
\text { to viral culture. }\end{array}$ & $\begin{array}{l}\text { Case definition } \\
\text { cited; laboratory } \\
\text { test cut-off values } \\
\text { not reported. }\end{array}$ & $\begin{array}{l}\text { Cross-sectional study, no } \\
\text { follow-up. }\end{array}$ & $\begin{array}{l}\text { Study was designed to } \\
\text { investigate performance } \\
\text { of a rapid antigen test, } \\
\text { using RT-PCR as the } \\
\text { standard. Onward } \\
\text { transmission was not } \\
\text { investigated. }\end{array}$ \\
\hline $\begin{array}{l}\text { Soto } \\
\text { (April-May } \\
2020)\end{array}$ & $\begin{array}{l}\text { Emergency } \\
\text { childcare } \\
\text { centre } \\
\text { contacts, } \\
\text { Quebec, } \\
\text { Canada }\end{array}$ & $\begin{array}{l}\text { Outbreak study in } \\
\text { an emergency } \\
\text { childcare centre, } \\
\text { including } 120 \\
\text { children, employees } \\
\text { and household } \\
\text { contacts of } \\
\text { confirmed COVID- } \\
19 \text { cases. }\end{array}$ & $\begin{array}{l}\text { NP swabs were } \\
\text { subjected to RT-PCR. } \\
\text { Nucleic acids were } \\
\text { extracted from NP } \\
\text { samples and subjected } \\
\text { to reverse transcription } \\
\text { for phylogenetic } \\
\text { analyses. }\end{array}$ & $\begin{array}{l}\text { Algorithm for } \\
\text { deciding cases is } \\
\text { reported; PCR Ct } \\
\text { cut-offs not } \\
\text { reported. }\end{array}$ & $\begin{array}{l}\text { Definition of symptoms } \\
\text { collected not reported and } \\
\text { asymptomatic not defined }\end{array}$ & $\begin{array}{l}\text { Epidemiology (social } \\
\text { network analysis) and } \\
\text { phylogeny were used. } \\
\text { Unclear but assume } \\
\text { screening of all children } \\
\text { and staff at the childcare } \\
\text { centre; report states that } \\
\text { within household } \\
\text { contacts, only }\end{array}$ \\
\hline
\end{tabular}




\begin{tabular}{|c|c|c|c|c|c|c|}
\hline & & & & & & $\begin{array}{l}\text { symptomatics were } \\
\text { tested. }\end{array}$ \\
\hline $\begin{array}{l}\text { Speake } \\
\text { (March - } \\
\text { April 2020) }\end{array}$ & $\begin{array}{l}\text { Passengers } \\
\text { on a 5-hour } \\
\text { domestic } \\
\text { flight, } \\
\text { Australia; } \\
\text { some } \\
\text { passengers } \\
\text { had arrived } \\
\text { from abroad, } \\
\text { including from } \\
\text { cruise ships. }\end{array}$ & $\begin{array}{l}\text { To investigate the } \\
\text { possible } \\
\text { transmission of } \\
\text { SARS-CoV-2 on a } \\
\text { commercial airline } \\
\text { flight, using whole } \\
\text { genome sequencing } \\
\text { to support evidence } \\
\text { on chains of } \\
\text { transmission. }\end{array}$ & $\begin{array}{l}\text { PCR testing was applied } \\
\text { to throat swabs and } \\
\text { bilateral NP or deep } \\
\text { nasal swabs from } \\
\text { symptomatic individuals. } \\
\text { Genome sequencing } \\
\text { performed where } \\
\text { possible (if multiple } \\
\text { samples were available } \\
\text { from a participant, } \\
\text { samples with lowest } \\
\text { Ct values used). Virus } \\
\text { culture was attempted } \\
\text { for all samples sent to } \\
\text { one of the two } \\
\text { laboratories used. }\end{array}$ & $\begin{array}{l}\text { Case definition } \\
\text { according to } \\
\text { symptomatology } \\
\text { and/or a closely } \\
\text { matching virus } \\
\text { genomic } \\
\text { sequence. }\end{array}$ & $\begin{array}{l}\text { Symptoms compatible } \\
\text { with COVID-19 led to } \\
\text { testing. }\end{array}$ & $\begin{array}{l}\text { People were only tested } \\
\text { for SARS-CoV-2 if they } \\
\text { had significant symptoms } \\
\text { (testing capacity not } \\
\text { sufficient to include } \\
\text { people without } \\
\text { symptoms) }\end{array}$ \\
\hline $\begin{array}{l}\text { Surie } \\
\text { (June-Aug } \\
2020 \text { ) }\end{array}$ & $\begin{array}{l}\text { Elderly care } \\
\text { home } \\
\text { residents with } \\
\text { underlying } \\
\text { health } \\
\text { conditions, } \\
\text { Arkansas, } \\
\text { USA }\end{array}$ & $\begin{array}{l}\text { To estimate the } \\
\text { infectious period of } \\
\text { SARS-CoV-2 in } \\
\text { elderly care home } \\
\text { residents with } \\
\text { underlying } \\
\text { conditions, using } \\
\text { symptom recording. } \\
17 / 39 \text { nursing home } \\
\text { residents (all PCR } \\
\text { positive, all } \\
\text { eventually } \\
\text { symptomatic) were } \\
\text { followed } \\
\text { prospectively to }\end{array}$ & $\begin{array}{l}\text { OP and anterior nares } \\
\text { swabs and saliva } \\
\text { samples collected and } \\
\text { tested using RT-PCR. } \\
\text { All positive samples } \\
\text { were subjected to viral } \\
\text { culture. Where CPE in } \\
\text { viral culture was } \\
\text { observed RT-PCR was } \\
\text { used to confirm the } \\
\text { presence of SARS-CoV- } \\
2 . \text { Collection of blood } \\
\text { (for serology) attempted } \\
\text { at enrollment and at visit } \\
\text { days } 6,12,21 \text {, and } 42 \text {. }\end{array}$ & Not reported. & $\begin{array}{l}\text { Symptoms of shortness of } \\
\text { breath, cough, malaise, } \\
\text { muscle pain, dizziness, } \\
\text { diarrhea, vomiting, sore } \\
\text { throat, and headache } \\
\text { assessed by HCW } \\
\text { (before enrollment). At } \\
\text { enrollment and each } \\
\text { subsequent visit, } \\
\text { participants were } \\
\text { interviewed using the } \\
\text { CDC standard list of } \\
\text { symptoms, to }\end{array}$ & $\begin{array}{l}\text { Infectivity was defined as } \\
\text { isolation of replication- } \\
\text { competent virus } \\
\text { from a specimen in cell } \\
\text { culture }\end{array}$ \\
\hline
\end{tabular}




\begin{tabular}{|c|c|c|c|c|c|c|}
\hline & & $\begin{array}{l}\text { examine viral } \\
\text { shedding duration, } \\
\text { and viral culture } \\
\text { was done to assess } \\
\text { infectivity. }\end{array}$ & & & $\begin{array}{l}\text { which chest and } \\
\text { abdominal pain were } \\
\text { added. } \\
\text { Participants followed for } \\
42 \text { days after enrollment } \\
\text { in study. Symptom } \\
\text { assessment, medical } \\
\text { record review, sample } \\
\text { collection done at each } \\
\text { study visit. }\end{array}$ & \\
\hline $\begin{array}{l}\text { Taylor } \\
\text { (March-May } \\
2020)\end{array}$ & $\begin{array}{l}\text { Outbreak } \\
\text { investigation } \\
\text { at army } \\
\text { barracks, } \\
\text { London, UK }\end{array}$ & $\begin{array}{l}\text { Study to monitor } \\
\text { SARS-CoV-2 } \\
\text { infection and } \\
\text { antibodies in } \\
\text { soldiers, their family } \\
\text { and civilians; also to } \\
\text { correlate SARS- } \\
\text { CoV-2 infection and } \\
\text { antibody positivity } \\
\text { with clinical } \\
\text { symptoms and } \\
\text { signs. }\end{array}$ & $\begin{array}{l}\text { Screening of army } \\
\text { personnel, their families } \\
\text { and civilian contacts was } \\
\text { done twice } 36 \text { days } \\
\text { apart. Nasal swabs, } \\
\text { throat swabs and blood } \\
\text { samples taken. } \\
\text { Respiratory samples } \\
\text { subjected to rtRT-PCR. } \\
\text { Positive samples with } \\
\text { Ct<35 subjected to } \\
\text { whole genome } \\
\text { sequencing and to virus } \\
\text { isolation on Vero E6 } \\
\text { cells; virus detection } \\
\text { confirmed by CPE up to } \\
14 \text { days after } \\
\text { inoculation. Serum } \\
\text { samples analysed for } \\
\text { SARS-CoV-2 antibodies. }\end{array}$ & Not reported & $\begin{array}{l}\text { Participant recalled } \\
\text { symptom onset and } \\
\text { timing, assessed by } \\
\text { questionnaire (including } \\
\text { fever, cough, sore throat, } \\
\text { runny nose, sneezing, } \\
\text { breathless, drowsy, } \\
\text { lethargic, seizures, coma, } \\
\text { muscle aches, rash, } \\
\text { vomiting, diarrhoea, loss } \\
\text { of appetite, conjunctivitis, } \\
\text { headache, loss of smell, } \\
\text { loss of taste, blurred } \\
\text { vision, other (state). }\end{array}$ & $\begin{array}{l}\text { No onward transmission } \\
\text { from asymptomatics } \\
\text { documented; samples } \\
\text { from asymptomatic } \\
\text { individuals were } \\
\text { assessed for infectivity } \\
\text { via viral culture, but } \\
\text { timeline of symptoms to } \\
\text { exclude previous or } \\
\text { subsequent symptoms is } \\
\text { not reported. }\end{array}$ \\
\hline $\begin{array}{l}\text { Van } \\
\text { Hensbergen } \\
\text { (March } \\
2020 \text { ) }\end{array}$ & $\begin{array}{l}99 \text { residents } \\
\text { of a long-term } \\
\text { care facility, } \\
\text { aged } 64 \text { to } 97 \\
\text { years, The } \\
\text { Netherlands. }\end{array}$ & $\begin{array}{l}\text { Cross-sectional } \\
\text { outbreak } \\
\text { investigation in a } \\
\text { care home. }\end{array}$ & $\begin{array}{l}\text { Throat and NP swabs } \\
\text { taken for PCR testing. } \\
\text { cycle count numbers } \\
\text { determined. WGS } \\
\text { performed on samples. } \\
\text { Residents with relevant }\end{array}$ & $\begin{array}{l}\text { Clinical case } \\
\text { definition reported. }\end{array}$ & $\begin{array}{l}\text { On the day of survey, } \\
\text { HCWs performed semi- } \\
\text { structured oral interviews } \\
\text { of all residents, to collect } \\
\text { information on age, sex, } \\
\text { new or unusual signs and }\end{array}$ & $\begin{array}{l}\text { Some residents had } \\
\text { some impaired cognition, } \\
\text { which may have } \\
\text { prevented full recording } \\
\text { of signs and symptoms. }\end{array}$ \\
\hline
\end{tabular}




\begin{tabular}{|c|c|c|c|c|c|c|}
\hline & & & $\begin{array}{l}\text { symptoms or recent } \\
\text { contact or } \\
\text { epidemiological history } \\
\text { were tested; additionally } \\
12 \text { random samples } \\
\text { from residents without } \\
\text { symptoms were taken. }\end{array}$ & & $\begin{array}{l}\text { symptoms of disease, } \\
\text { complemented with } \\
\text { comorbidity information } \\
\text { from their patient records } \\
\text { and taking their } \\
\text { temperature (rectally) in } \\
\text { the morning and the } \\
\text { evening (subfebrile: } 37.5- \\
38^{\circ} \mathrm{C} \text {; fever: } 38.0^{\circ} \mathrm{C} \text { and } \\
\text { above). Symptoms: fever, } \\
\text { subfebrile temperature, } \\
\text { cough, fatigue, malaise, } \\
\text { vomiting, loss of appetite, } \\
\text { nausea, and dizziness }\end{array}$ & \\
\hline $\begin{array}{l}\text { Wallace } \\
\text { (May-June } \\
2020 \text { ) }\end{array}$ & $\begin{array}{l}\text { Detainees in } \\
\text { a detention } \\
\text { centre, } \\
\text { Louisiana, } \\
\text { USA. }\end{array}$ & $\begin{array}{l}\text { Prospective cohort } \\
\text { study using serial } \\
\text { testing of detainees } \\
\text { initiated } 2 \text { to } 4 \\
\text { weeks after } \\
\text { identification of } \\
\text { SARS-CoV-2 } \\
\text { infection in staff and } \\
\text { detainees. } \\
\text { Dormitories had } \\
\text { shared toilets and } \\
\text { bathroom facilities. }\end{array}$ & $\begin{array}{l}\text { NP swabs were tested } \\
\text { by rRT-PCR. Ct }<40 \\
\text { considered positive and } \\
\text { those specimens were } \\
\text { subjected to culture; } \\
\text { also nucleic acid } \\
\text { extracted and } \\
\text { sequenced. }\end{array}$ & $\begin{array}{l}\text { Ct }<40 \text { considered } \\
\text { positive }\end{array}$ & $\begin{array}{l}\text { Symptom questionnaire, } \\
\text { self-administered on each } \\
\text { survey day. }\end{array}$ & $\begin{array}{l}\text { Authors state: } \\
\text { "...detained persons } \\
\text { might have limited recall } \\
\text { of mild symptoms and } \\
\text { symptom timing, } \\
\text { particularly symptoms } \\
\text { occurring }>2 \text { weeks } \\
\text { before testing, potentially } \\
\text { resulting in an } \\
\text { overestimation of the } \\
\text { prevalence of } \\
\text { asymptomatic infection." }\end{array}$ \\
\hline
\end{tabular}


Appendix C - Quality Assessment of Symptom ascertainment

\begin{tabular}{|c|c|c|c|c|c|c|}
\hline Study & Symptom Methods description & Symptomatic & Asymptomatic & Presymptomatic & $\begin{array}{l}\text { Potential for } \\
\text { symptom } \\
\text { ascertainment } \\
\text { bias }\end{array}$ & $\begin{array}{l}\text { Reasons for the bias } \\
\text { assessment }\end{array}$ \\
\hline Arons 2020 & $\begin{array}{l}\text { A standardized symptom } \\
\text { assessment form was completed } \\
\text { by nurses for each resident tested. } \\
\text { Symptoms present during the } \\
\text { preceding } 14 \text { days were recorded } \\
\text { based on interviews and review of } \\
\text { medical records. Asymptomatic } \\
\text { residents with +ve test were } \\
\text { reassessed for symptoms } 7 \text { days } \\
\text { later. }\end{array}$ & $\begin{array}{l}\text { Symptomatic with typical } \\
\text { symptoms: subjective fever or T } \\
>37.8^{\circ} \mathrm{C}, \text { cough, or SOB } \\
\text { Symptomatic with atypical } \\
\text { symptoms: if symptoms included } \\
\text { only chills, malaise, increased } \\
\text { confusion, rhinorrhea, nasal } \\
\text { congestion, sore throat, myalgia, } \\
\text { dizziness, headache, nausea, or } \\
\text { diarrhoea. } \\
\text { At least one new or worsened } \\
\text { symptom in the preceding } 14 \text { days. }\end{array}$ & $\begin{array}{l}\text { Asymptomatic residents } \\
\text { were those who had no } \\
\text { symptoms or only stable } \\
\text { chronic symptoms (e.g., } \\
\text { chronic cough without } \\
\text { worsening). Residents who } \\
\text { did not develop symptoms } \\
\text { in the } 7 \text { days after testing } \\
\text { remained classified as } \\
\text { asymptomatic. }\end{array}$ & $\begin{array}{l}\text { Presymptomatic } \\
\text { residents were those } \\
\text { who were } \\
\text { asymptomatic at the } \\
\text { time of testing but } \\
\text { developed symptoms } \\
\text { within } 7 \text { days after } \\
\text { testing. }\end{array}$ & Moderate & $\begin{array}{l}\text { Chronic symptom } \\
\text { escalation is a subjective } \\
\text { assessment, } \\
\text { retrospective and elderly } \\
\text { may present with more } \\
\text { subtle symptoms that } \\
\text { require clinical } \\
\text { assessment. }\end{array}$ \\
\hline Borges 2021 & No description & No details & No details & No details & High & $\begin{array}{l}\text { No definition and no } \\
\text { follow-up. Cannot discard } \\
\text { mild symptoms }\end{array}$ \\
\hline Cordery 2021 & $\begin{array}{l}\text { Prior health conditions, symptom } \\
\text { description, and contact } \\
\text { history of cases were collected by } \\
\text { questionnaire, completed by } \\
\text { parent or guardian }\end{array}$ & $\begin{array}{l}\text { All symptomatic cases where the } \\
\text { virus was detected reported fever } \\
\text { and one other symptom, except one } \\
\text { case. This case reported cough and } \\
\text { anosmia, but no fever. }\end{array}$ & No details & No details & High & $\begin{array}{l}\text { No methods for } \\
\text { asymptomatic and } \\
\text { presymptomatic } \\
\text { assessment were } \\
\text { reported. The authors } \\
\text { note differences in illness } \\
\text { severity or symptom } \\
\text { recall }\end{array}$ \\
\hline
\end{tabular}




\begin{tabular}{|c|c|c|c|c|c|c|}
\hline de Laval 2021 & $\begin{array}{l}\text { Cases were interviewed at length } \\
\text { about symptoms and date of onset } \\
\text { and about their activities and } \\
\text { contacts in the } 14 \text { days prior to } \\
\text { symptom onset. The interviewers } \\
\text { used a standardized } \\
\text { questionnaire. }\end{array}$ & $\begin{array}{l}\text { Fever } \geq 38^{\circ} \mathrm{C} \text {, cough, myalgia, } \\
\text { asthenia, rhinorrhea, headache, } \\
\text { odynophagia, dyspnea and } \\
\text { diarrhoea. At that time, did not } \\
\text { systematically ask about } \\
\text { ageusia/anosmia; five patients } \\
\text { declared them spontaneously. }\end{array}$ & No details & No details & High & $\begin{array}{l}\text { No methods for } \\
\text { asymptomatic and } \\
\text { presymptomatic } \\
\text { assessment were } \\
\text { reported. Limited } \\
\text { symptoms assessed and } \\
\text { lack of follow-up }\end{array}$ \\
\hline Ferreira 2021 & $\begin{array}{l}\text { Absence of symptoms was } \\
\text { confirmed for all participants at the } \\
\text { time of testing. HCWs were } \\
\text { required to be asymptomatic and } \\
\text { not have a previous diagnosis of } \\
\text { COVID-19. Symptoms included } \\
\text { fever, headache, new or } \\
\text { worsening cough, shortness of } \\
\text { breath, sore throat, rhinorrhea, } \\
\text { diarrhoea, anosmia, myalgias, and } \\
\text { conjunctivitis }\end{array}$ & $\begin{array}{l}\text { HCWs symptomatic HCWs who self- } \\
\text { identified as having at least one } \\
\text { symptom compatible with COVID-19. }\end{array}$ & $\begin{array}{l}\text { No symptoms in the } 2 \\
\text { weeks following testing }\end{array}$ & $\begin{array}{l}\text { Development of } \\
\text { Symptoms in the } 2 \\
\text { weeks following } \\
\text { testing }\end{array}$ & High & $\begin{array}{l}\text { No pre-assessment of } \\
\text { symptoms, restricted list } \\
\text { and no methods of how } \\
\text { the symptoms were } \\
\text { assessed }\end{array}$ \\
\hline Francis 2021 & $\begin{array}{l}\text { No methods for symptom } \\
\text { assessment were reported. } \\
\text { Limited symptoms assessed and } \\
\text { lack of follow-up. }\end{array}$ & No details & No details & No details & High & $\begin{array}{l}\text { No methods for symptom } \\
\text { assessment were } \\
\text { reported. }\end{array}$ \\
\hline
\end{tabular}




\begin{tabular}{|c|c|c|c|c|c|c|}
\hline $\begin{array}{l}\text { Gettings } \\
2021\end{array}$ & $\begin{array}{l}\text { Community members performed } \\
\text { self-screening for symptoms. } \\
\text { Project staff contacted school } \\
\text { contacts to obtain verbal consent } \\
\text { to participate in the investigation, } \\
\text { offer SARS-CoV-2 RT-PCR } \\
\text { testing, and collect symptom } \\
\text { information at the time of testing. } \\
\text { Project staff also monitored } \\
\text { symptoms for } 14 \text { days through } \\
\text { daily text-message based } \\
\text { symptom monitoring }\end{array}$ & $\begin{array}{l}\text { Council of State and Territorial } \\
\text { Epidemiologists (CSTE) case } \\
\text { definition for COVID-19* }\end{array}$ & No details & No details & High & $\begin{array}{l}\text { Self-screening and } \\
\text { problems with symptom } \\
\text { recall, no definitions and } \\
\text { symptoms pre-testing }\end{array}$ \\
\hline $\begin{array}{l}\text { Hershow } \\
2021\end{array}$ & $\begin{array}{l}\text { School contacts of identified index } \\
\text { patients completed a questionnaire } \\
\text { about symptoms and exposures } \\
\text { and received SARS-CoV-2 testing. }\end{array}$ & No details & No details & No details & High & $\begin{array}{l}\text { No methods for symptom } \\
\text { assessment reported }\end{array}$ \\
\hline Jeffery-Smith & $\begin{array}{l}\text { Symptom status during the } 14 \\
\text { days before and at the time of } \\
\text { swabbing was collected for all } \\
\text { staff, who self-reported symptoms, } \\
\text { and residents symptoms were } \\
\text { recorded by the care home staff. } \\
\text { Daily interviews were undertaken } \\
\text { with individual care homes to } \\
\text { identify symptomatics. }\end{array}$ & $\begin{array}{l}\text { Typical: fever } \geq 37.8^{\circ} \mathrm{C}, \mathrm{SOB} \text { or } \\
\text { cough, } \\
\text { Atypical: included, but not restricted } \\
\text { to, new confusion, reduced alertness, } \\
\text { fatigue, lethargy, reduced mobility } \\
\text { and diarrhoea. }\end{array}$ & No details & No details & High & $\begin{array}{l}\text { Did not collect extensive } \\
\text { individual-level } \\
\text { information such as } \\
\text { comorbidities, range and } \\
\text { duration of individual } \\
\text { symptoms }\end{array}$ \\
\hline
\end{tabular}




\begin{tabular}{|c|c|c|c|c|c|c|}
\hline Lewis 2021 & $\begin{array}{l}\text { Before the day } 0 \text { visit, } \\
\text { questionnaires were administered } \\
\text { to all index patients and household } \\
\text { contacts by telephone to request } \\
\text { demographic information and data } \\
\text { on symptoms onset, exposure to } \\
\text { the index patient and others } \\
\text { outside the household, and any } \\
\text { previous SARS-CoV-2 testing. } \\
\text { During days } 0-14 \text {, all index } \\
\text { patients and household members } \\
\text { completed a daily symptom diary. } \\
\text { Symptoms grouped according to } \\
\text { Council of State and Territorial } \\
\text { Epidemiologists (CSTE) }\end{array}$ & $\begin{array}{l}\text { Classic (cough, shortness of breath, } \\
\text { or discomfort while breathing), } \\
\text { Nonclassic: }>2 \text { of measured or } \\
\text { subjective fever, chills, headache, } \\
\text { myalgia, sore throat, loss of taste, or } \\
\text { loss of smell) } \\
\text { Asyndromic: Any symptoms other } \\
\text { than classic or nonclassic: fatigue, } \\
\text { runny nose, nasal congestion, chest } \\
\text { pain, wheezing, nausea or vomiting, } \\
\text { or diarrhoea. } \\
\text { Other categories } \\
\text { Neurologic: Loss of taste (partial or } \\
\text { complete), loss of smell (partial or } \\
\text { complete), or headache. } \\
\text { Lower Resp: \#Discomfort while } \\
\text { breathing, wheezing, shortness of } \\
\text { breath, chest pain, or cough (dry or } \\
\text { productive). } \\
\text { Upper Resp: **Sore throat, nasal } \\
\text { congestion, or runny nose. } \\
\text { Constitutional: Chills, fever } \\
\text { (measured or subjective), fatigue, or } \\
\text { myalgia. } \\
\text { Gastro: Abdominal pain, nausea or } \\
\text { vomiting, or diarrhoea. }\end{array}$ & & $\begin{array}{l}\text { Presymptomatic } \\
\text { shedding was defined } \\
\text { as symptom onset }>1 \\
\text { day after the first } \\
\text { positive SARS-CoV-2 } \\
\text { result by rRT-PCR. }\end{array}$ & Moderate & $\begin{array}{l}\text { Symptom data relied on } \\
\text { self-reporting, and } \\
\text { symptoms might have } \\
\text { been present before or } \\
\text { after they were reported } \\
\text { by patients. }\end{array}$ \\
\hline Murata 2021 & $\begin{array}{l}\text { Asymptomatic status was } \\
\text { determined at the time of testing } \\
\text { by physicians and nurses who } \\
\text { were mobilized to the ship from } \\
\text { quarantine stations, the self- } \\
\text { defence forces, and disaster } \\
\text { medical assistance teams. Body } \\
\text { temperature, oxygen saturation, } \\
\text { and symptoms were monitored at } \\
\text { least twice a day, and the } \\
\text { nasopharyngeal swabs were } \\
\text { collected approximately every } 48 \mathrm{~h}\end{array}$ & $\begin{array}{l}\text { signs and symptoms consistent with } \\
\text { COVID-19 (i.e., fever of } \geq 37.5^{\circ} \mathrm{C} \text {, } \\
\text { oxygen saturation of } \leq 93 \% \text { without } \\
\text { supplemental oxygen, or new onset } \\
\text { of respiratory symptoms) }\end{array}$ & $\begin{array}{l}\text { Asymptomatic status } \\
\text { determined at the time of } \\
\text { testing based on the } \\
\text { absence of fever } \\
\text { (temperature of } \geq 37.5^{\circ} \mathrm{C} \text { ) } \\
\text { and clinical symptoms } \\
\text { (cough, dyspnea, chest } \\
\text { pain, sore throat, and nasal }\end{array}$ & Not applicable & High & $\begin{array}{l}\text { The timing of the } \\
\text { exposure to/infection was } \\
\text { not ascertained. Only } \\
\text { typical symptoms were } \\
\text { assessed. Olfactory and } \\
\text { gustatory impairment } \\
\text { was not recognized as } \\
\text { characteristic of COVID- } \\
19 \text { at the time and was } \\
\text { not routinely checked. }\end{array}$ \\
\hline
\end{tabular}




\begin{tabular}{|c|c|c|c|c|c|c|}
\hline & $\begin{array}{l}\text { until two consecutive negative } \\
\text { PCR test results were obtained. }\end{array}$ & & discharge) & & & \\
\hline Pray 2021 & $\begin{array}{l}\text { All participants completed a } \\
\text { questionnaire and provided } \\
\text { information on demographic } \\
\text { characteristics, current and past } \\
\text { (14 days) symptoms. The } \\
\text { symptom list was based on the } \\
\text { interim position statement for } \\
\text { COVID-19 case definitions from } \\
\text { the Council of State and Territorial } \\
\text { Epidemiologists, updated August } \\
7,2020 .^{*}\end{array}$ & $\begin{array}{l}\text { Clinical criteria for COVID-19 } \\
\text { included fever, cough, shortness of } \\
\text { breath, fatigue, sore throat, } \\
\text { headache, muscle aches, chills, } \\
\text { nasal congestion, difficulty breathing, } \\
\text { diarrhoea, nausea, vomiting, } \\
\text { abdominal pain, rigours, loss of taste, } \\
\text { and loss of smell. }\end{array}$ & No details & No details & High & $\begin{array}{l}\text { A limited set of } \\
\text { symptoms, self-report, } \\
\text { recall bias and no } \\
\text { information on follow-up } \\
\text { and no presymptomatic } \\
\text { assessment }\end{array}$ \\
\hline Soto 2020 & $\begin{array}{l}\text { Household contacts were } \\
\text { monitored daily for symptoms and } \\
\text { only symptomatic contacts were } \\
\text { tested. }\end{array}$ & $\begin{array}{l}\text { Clinical manifestations compatible } \\
\text { with COVID-19 }\end{array}$ & No details & No details & High & $\begin{array}{l}\text { No methods for symptom } \\
\text { assessment reported }\end{array}$ \\
\hline
\end{tabular}




\begin{tabular}{|c|c|c|c|c|c|c|}
\hline Speake 2020 & $\begin{array}{l}\text { Passenger's self-reported date of } \\
\text { symptom onset. Asymptomatics } \\
\text { were not tested but pre- } \\
\text { symptomatics were }\end{array}$ & No details & No details & No details & High & $\begin{array}{l}\text { No methods for symptom } \\
\text { assessment reported }\end{array}$ \\
\hline Surie D 2021 & $\begin{array}{l}\text { Each participant followed for } 42 \\
\text { days from enrollment. For the first } \\
21 \text { days, participants visit every } 3 \\
\text { days; for the next } 21 \text { days, } \\
\text { participants visited weekly. } \\
\text { Symptom assessment, medical } \\
\text { chart review were repeated at } \\
\text { each visit. At enrollment and visits, } \\
\text { participants were interviewed by } \\
\text { project staff about symptoms. } \\
\text { Symptoms before enrollment were } \\
\text { assessed by healthcare personnel } \\
\text { at the facility using a standard } \\
\text { symptom list that was different } \\
\text { from the symptom assessment } \\
\text { used by study staff after } \\
\text { enrollment. }\end{array}$ & $\begin{array}{l}\text { Centers for Disease Control and } \\
\text { Prevention (CDC)* standard list of } \\
\text { symptoms, to which chest and } \\
\text { abdominal pain were added. } \\
\text { Symptoms at } \\
\text { Reported Symptoms: Cough, } \\
\text { Dyspnea, Fatigue, Myalgias, } \\
\text { Rhinorrhea, Sore throat, } \\
\text { Nausea/vomiting, Diarrhea, } \\
\text { Abdominal pain, Headache, } \\
\text { Anosmia, Fever ( } \geq 100 o F) \text {, Subjective } \\
\text { fever, Dysgeusia, Chills, Chest pain } \\
\text { and Severe COVID-19 illness } \\
\text { Severe illness is defined as oxygen } \\
\text { saturation (SpO2) decrease of }>3 \% \\
\text { from baseline }\end{array}$ & $\begin{array}{l}39 \text { nursing home residents } \\
\text { (all PCR +ve, all eventually } \\
\text { symptomatic }\end{array}$ & No details & Moderate & $\begin{array}{l}\text { Patients often had } \\
\text { difficulty distinguishing } \\
\text { acute from chronic } \\
\text { symptoms, especially for } \\
\text { nonspecific symptoms } \\
\text { such as fatigue and } \\
\text { myalgia. Data collected } \\
\text { before enrollment used } \\
\text { the facility's symptom } \\
\text { assessment tool, which } \\
\text { did not include all } \\
\text { symptoms tracked during } \\
\text { the ongoing assessment, } \\
\text { it is possible early } \\
\text { symptoms could have } \\
\text { been missed, }\end{array}$ \\
\hline
\end{tabular}


Participants completed a short questionnaire on demographics, living arrangements, contacts and symptoms in the past month.

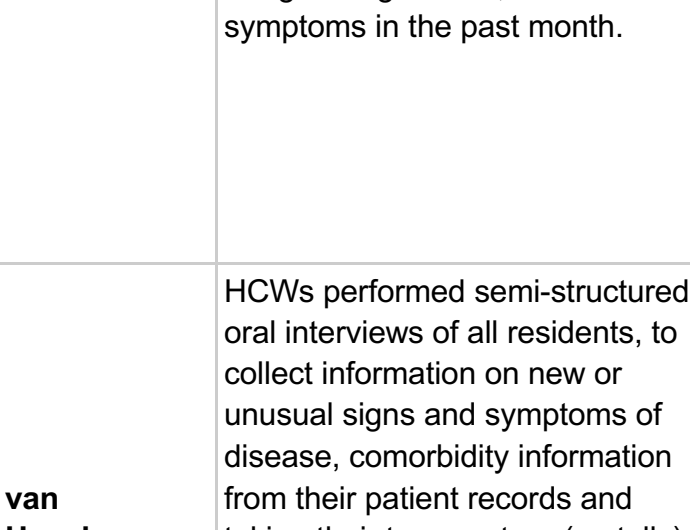

Hensbergen taking their temperature (rectally)

2020
Fever at any time, Cough, Sore

throat, Runny nose, Sneezing,

Breathless, Drowsy, Lethargic,

Seizures, Coma, Muscle aches,

Rash, Vomiting, Diarrhoea, Loss of

No details

No details

High apetite, Conjunctivitis

Headache, Loss of Smell, Loss of

taste, Blurred vision: Other as stated.

fever, cough or dyspnoea. fatigue,

malaise, vomiting, loss of appetite,

No details

No details
Relied on participant

recall for symptom onset

and timing, most were

not tested for SARS-

CoV-2 infection prior to

the investigation. At least

some reported illnesses

were likely due to other

viruses, as highlighted by

the picornavirus infection

in one participant and

therefore, the true rate of

asymptomatic infection

may be underestimated

Optimal collection of

signs and symptoms was

hampered because

residents had some

stage of impaired

cognition.

Unable to acquire any

follow-up data on

symptoms, which made it

impossible to categorize

any asymptomatic

residents as pre-

symptomatic residents 


\begin{tabular}{|c|c|c|c|c|c|c|}
\hline Wallace 2021 & $\begin{array}{l}\text { The investigation team } \\
\text { administered a structured } \\
\text { dormitory survey among facility } \\
\text { staff to assess physical layout, } \\
\text { capacity, activities, and practices. } \\
\text { During day } 0 \text { testing, detained } \\
\text { persons completed a self- } \\
\text { administered, paper-based } \\
\text { questionnaire of symptoms in the } \\
\text { preceding } 2 \text { months and } 2 \text { weeks, } \\
\text { facility exposures, and preventive } \\
\text { measures. On the day of each } \\
\text { subsequent test, detained persons } \\
\text { received an abbreviated self- } \\
\text { administered, paper-based } \\
\text { questionnaire of symptoms } \\
\text { experienced since the last testing } \\
\text { day. The team verbally verified } \\
\text { responses with detained persons } \\
\text { and assisted as necessary. } \\
\text { Medical history data were } \\
\text { abstracted from facility medical } \\
\text { records. Persons were categorized } \\
\text { as presymptomatic, symptomatic, } \\
\text { post symptomatic, or } \\
\text { asymptomatic on the basis of } \\
\text { symptoms at sample collection. } \\
\text { Any CDC-listed coronavirus } \\
\text { symptom with a reported onset } \\
\text { date on or after March } 29,2020, \\
\text { the illness onset date of the first } \\
\text { reported COVID-19 case in the } \\
\text { facility, was included in analyses. } \\
\text { Persons were classified as having } \\
\text { an unknown symptom status if any } \\
\text { symptom data were missing and } \\
\text { no symptoms were reported }\end{array}$ & $\begin{array}{l}\text { if }>1 \text { present or ongoing symptom } \\
\text { Symptomatic (at any point), } \\
\text { Headache, Loss of taste or smell, } \\
\text { Nasal congestion, Rhinorrhea, } \\
\text { Subjective fever, Chills, Myalgia, } \\
\text { Cough, Abdominal pain, Diarrhea, } \\
\text { Dyspnea, Sore throat, Nausea, } \\
\text { Vomiting and Measured fever }\end{array}$ & $\begin{array}{l}\text { Asymptomatic persons } \\
\text { reported no symptoms } \\
\text { throughout the investigation. }\end{array}$ & $\begin{array}{l}\text { Presymptomatic } \\
\text { persons reported }>1 \\
\text { symptom with onset } \\
\text { after their first positive } \\
\text { test result and had no } \\
\text { previously reported } \\
\text { symptoms. }\end{array}$ & Moderate & $\begin{array}{l}\text { Symptoms occurring }>2 \\
\text { weeks before testing, } \\
\text { potentially resulting in an } \\
\text { overestimation of the } \\
\text { prevalence of } \\
\text { asymptomatic infection. } \\
\text { Also, follow-up symptom } \\
\text { assessments were not } \\
\text { conducted among } \\
\text { persons with positive test } \\
\text { results from dormitory F, } \\
\text { thus potential } \\
\text { presymptomatic detained } \\
\text { persons remained } \\
\text { classified as } \\
\text { asymptomatic. Inclusion } \\
\text { of symptoms reported up } \\
\text { to } 6 \text { weeks before } \\
\text { testing, misclassification } \\
\text { of symptoms caused by } \\
\text { other pathogens or } \\
\text { allergies could have } \\
\text { occurred. }\end{array}$ \\
\hline
\end{tabular}




\section{REFERENCES}

1. Heneghan, C., et al., SARS-CoV-2 and the role of airborne transmission: a systematic review [version 1; peer review: awaiting peer review]. F1000Research, 2021. 10:232. https://doi.org/10.12688/f1000research.52091.1.

2. Heneghan, C., et al., SARS-CoV-2 and the role of orofecal transmission: a systematic review [version 1; peer review: awaiting peer review]. F1000Research, 2021. 10(231). 10.12688/f1000research.51592.1.

3. Onakpoya, I., et al., SARS-CoV-2 and the role of close contact in transmission: a systematic review [version 1; peer review: awaiting peer review]. F1000Research, 2021. 10(280). 10.12688/f1000research.52439.1.

4. Onakpoya, I., et al., SARS-CoV-2 and the role of close contact in transmission: a systematic review [version 1; peer review: awaiting peer review]. F1000Research, 2021. 10(280). 10.12688/f1000research.52439.1.

5. Meyerowitz, E.A., et al., Towards an accurate and systematic characterisation of persistently asymptomatic infection with SARS-CoV-2. The Lancet Infectious Diseases. 10.1016/S1473-3099(20)30837-9.

6. Byambasuren, O., et al., Estimating the extent of asymptomatic COVID-19 and its potential for community transmission: systematic review and meta-analysis. medRxiv, 2020: p. 2020.05.10.20097543. 10.1101/2020.05.10.20097543.

7. Cevik, M., et al., SARS-CoV-2, SARS-CoV-1 and MERS-CoV viral load dynamics, duration of viral shedding and infectiousness: a living systematic review and meta-analysis. medRxiv, 2020: p. 2020.07.25.20162107. 10.1101/2020.07.25.20162107.

8. Jefferson, T., et al., Viral cultures for COVID-19 infectivity assessment. Systematic review. medRxiv, 2020: p. 2020.08.04.20167932. 10.1101/2020.08.04.20167932.

9. Buitrago-Garcia D, E.-G.D., Counotte and H.S. MJ, Imeri H, Ipekci AM, et al., Occurrence and transmission potential of asymptomatic and presymptomatic SARS-CoV-2 infections: A living systematic review and metaanalysis. PLoS Med 2020. 17(9). org/10.1371/journal.pmed.1003346.

10. Jefferson, T.H., C.; Spencer, E.; Brassey, J.; Pluddeman, A.; Onakpoya, I.; Evans, D.; Conly, J. A Hierarchical Framework for Assessing Transmission Causality of Respiratory Viruses. PrePrints, 2021. 10.20944/preprints202104.0633.v1.

11. Gwaltney, J.M., Jr. and J.O. Hendley, Rhinovirus transmission: one if by air, two if by hand. Am J Epidemiol, 1978. 107(5): p. 357-61. 10.1093/oxfordjournals.aje.a112555.

12. World Health Organisation. (2021). Genomic sequencing of SARS-CoV-2: a guide to implementation for maximum impact on public health. (Licence: CC BY-NC-SA 3.0 IGO.). Geneva.

13. Tricco AC, L.E., Zarin W, O'Brien KK, Colquhoun H, Levac D, Moher D, Peters MDJ, Horsley T, Weeks L, Hempel S, AkI EA, Chang C, McGowan J, Stewart L, Hartling L, Aldcroft A, Wilson MG, Garritty C, Lewin S, Godfrey CM, Macdonald MT, Langlois EV, Soares-Weiser 
K, Moriarty J, Clifford T, Tunçalp Ö, Straus SE, PRISMA Extension for Scoping Reviews (PRISMA-ScR): Checklist and Explanation. Ann Intern Med, 2018. 169(7): p. 467.473. 10.7326/M18-0850.

14. Bullard, J., et al., Infectivity of severe acute respiratory syndrome coronavirus 2 in children compared with adults. Canadian Medical Association Journal, 2021. 193(17): p. E601-E606. 10.1503/cmaj.210263.

15. Manca, A., et al., Non-corresponding authors in the era of meta-analyses. Journal of Clinical Epidemiology, 2018. 98: p. $159-161$. https://doi.org/10.1016/j.jclinepi.2018.01.009.

16. Böhmer, M.M., et al., Investigation of a COVID-19 outbreak in Germany resulting from a single travel-associated primary case: a case series. The Lancet Infectious Diseases, 2020. 20(8): p. 920-928. 10.1016/S1473-3099(20)30314-5.

17. Rothe, C., et al., Transmission of 2019-nCoV Infection from an Asymptomatic Contact in Germany. New England Journal of Medicine, 2020. 382(10): p. 970-971. 10.1056/NEJMc2001468.

18. Jefferson, T., et al., Viral cultures for COVID-19 infectious potential assessment - a systematic review. Clinical Infectious Diseases, 2020. $10.1093 /$ cid/ciaa1764.

19. America., I.D.S.o. IDSA and AMP joint statement on the use of SARS-CoV-2 PCR cycle threshold (Ct) values for clinical decisionmaking. 2021; Available from: https://www.idsociety.org/globalassets/idsa/public-health/covid-19/idsa-amp-statement.pdf.

20. Dawson, L., et al., Addressing Ethical Challenges in US-Based HIV Phylogenetic Research. The Journal of Infectious Diseases, 2020. 222(12): p. 1997-2006. 10.1093/infdis/jiaa107.

21. Jamrozik, E. and M.J. Selgelid, COVID-19 human challenge studies: ethical issues. The Lancet Infectious Diseases, 2020. 20(8): $\mathrm{p}$. e198-e203. https://doi.org/10.1016/S1473-3099(20)30438-2.

22. Patrozou, E. and L.A. Mermel, Does influenza transmission occur from asymptomatic infection or prior to symptom onset? (0033-3549 (Print)).

23. Murata, T., et al., Shedding of Viable Virus in Asymptomatic SARS-CoV-2 Carriers. mSphere. 0(0): p. e00019-21. 10.1128/mSphere.00019-21.

24. Lewis, N.M., et al., Characteristics and Timing of Initial Virus Shedding in Severe Acute Respiratory Syndrome Coronavirus 2, Utah, USA. Emerging infectious diseases, 2021. 27(2): p. 352-359. 10.3201/eid2702.203517.

25. Arons, M.M., et al., Presymptomatic SARS-CoV-2 Infections and Transmission in a Skilled Nursing Facility. New England Journal of Medicine, 2020. 382(22): p. 2081-2090. 10.1056/NEJMoa2008457. 